\title{
Dopamine Modulates Release from Corticostriatal Terminals
}

\author{
Nigel S. Bamford, ${ }^{1,2,5}$ Siobhan Robinson, ${ }^{3}$ Richard D. Palmiter, ${ }^{3,4}$ John A. Joyce, ${ }^{1}$ Cynthia Moore, ${ }^{6}$ and \\ Charles K. Meshul ${ }^{6}$ \\ ${ }^{1}$ Department of Neurology, ${ }^{2}$ Center on Human Development and Disability, ${ }^{3}$ Neurobiology and Behavior Program, and ${ }^{4}$ Howard Hughes Medical Institute, \\ University of Washington, and 5Department of Pediatrics, Children's Hospital and Regional Medical Center, Seattle, Washington 98195, and ${ }^{6}$ Veterans \\ Affairs Medical Center and Department of Behavioral Neuroscience, Oregon Health and Science University, Portland, Oregon 97239
}

\begin{abstract}
Normal striatal function is dependent on the availability of synaptic dopamine to modulate neurotransmission. Within the striatum, excitatory inputs from cortical glutamatergic neurons and modulatory inputs from midbrain dopamine neurons converge onto dendritic spines of medium spiny neurons. In addition to dopamine receptors on medium spiny neurons, D2 receptors are also present on corticostriatal terminals, where they act to dampen striatal excitation. To determine the effect of dopamine depletion on corticostriatal activity, we used the styryl dye FM1-43 in combination with multiphoton confocal microscopy in slice preparations from dopaminedeficient (DD) and reserpine-treated mice. The activity-dependent release of FM1-43 out of corticostriatal terminals allows a measure of kinetics quantified by the halftime decay of fluorescence intensity. In DD, reserpine-treated, and control mice, exposure to the D2-like receptor agonist quinpirole revealed modulation of corticostriatal kinetics with depression of FM1-43 destaining. In DD and reserpinetreated mice, quinpirole decreased destaining to a greater extent, and at a lower dose, consistent with hypersensitive corticostriatal D2 receptors. Compared with controls, slices from DD mice did not react to amphetamine or to cocaine with dopamine-releasing striatal stimulation unless the animals were pretreated with L-3,4-dihydroxyphenylalanine (L-dopa). Electron microscopy and immunogold labeling for glutamate terminals within the striatum demonstrated that the observed differences in kinetics of corticostriatal terminals in DD mice were not attributable to aberrant cytoarchitecture or glutamate density. Microdialysis revealed that basal extracellular striatal glutamate was normal in DD mice. These data indicate that dopamine deficiency results in morphologically normal corticostriatal terminals with hypersensitive D2 receptors.
\end{abstract}

Key words: dopamine deficiency; D2 receptor; corticostriatal; FM1-43 imaging; electronmicroscopy; microdialysis

\section{Introduction}

The striatum is the major point of entry into the basal ganglia for cortical information and plays an important role in motor control, cognition, and drug dependence (Albin et al., 1989; Jog et al., 1999). The basic striatal microcircuit (see Fig. $1 A$ ) is composed of medium spiny neurons (MSNs) that receive excitatory corticostriatal glutamatergic projections, forming asymmetric synaptic contacts on distal dendrites (Dube et al., 1988; Smith et al., 1994; Wilson, 1995), and dopaminergic nigrostriatal fibers that form symmetrical synapses on the necks of dendritic spines (Pickel et al., 1981). Although this anatomical configuration suggests that dopamine has a direct modulatory effect on cortical signaling (Arbuthnott et al., 1998), the role of dopamine in presynaptic modification of corticostriatal afferents has been controversial

\footnotetext{
Received July 16, 2004; revised Sept. 1, 2004; accepted Sept. 7, 2004.

This work was supported by the Child Neurology Society Young Investigator Award, University of Washington Royalty Research Award, Center on Human Development and Disability (Seattle, WA), Children's Hospital and Regional Medical Center (Seattle, WA), and Department of Veterans Affairs Merit Review Program to C.K.M. S.R. was supported by the National Institutes of Health Institutional Grant for Neurobiology (T32 GM07108-29). We thank Drs. David Sulzer, John Williams, Lisa Zimberg, and Thomas S. Hnasko and lan Bamford for helpful advice. We appreciate the support of the Colleen Giblin Charitable Foundation for Pediatric Neurology and the Vision Research Center, University of Washington, Seattle.

Correspondence should be addressed to Dr. Nigel S. Bamford, Department of Neurology, University of Washington, Box 356465, 1959 Northeast Pacific Street, Seattle, WA 98195. E-mail: bamford@u.washington.edu. D01:10.1523/JNEUROSCI.2891-04.2004

Copyright $\odot 2004$ Society for Neuroscience $\quad$ 0270-6474/04/249541-12\$15.00/0
}

because of the extraordinary complexity of MSN innervation (Akopian and Walsh, 2002) and the challenges inherent in using postsynaptic recordings to determine alterations in presynaptic activity (Van der Kloot, 1991; Sulzer and Pothos, 2000). Electron microscopy (Fisher et al., 1994; Sesack et al., 1994; Wang and Pickel, 2002) and electrophysiology (Calabresi et al., 1993; O’Donnell and Grace, 1994; Hsu et al., 1995; Flores-Hernandez et al., 1997; Cepeda et al., 2001; Tang et al., 2001; West and Grace, 2002; Bamford et al., 2004) studies, however, have supported the concept that dopamine directly regulates glutamate release from corticostriatal terminals by stimulating D2 receptors located on a subpopulation of cortical afferents, providing a mechanism for dampening critical cortical signals (Bamford et al., 2004).

In this study, we access the effect of acute and chronic dopamine depletion on corticostriatal terminals in striatal slice preparations from dopamine-deficient (DD) and reserpine-treated mice. DD mice were generated by a targeted deletion of the tyrosine hydroxylase ( $T h$ ) gene in dopamine neurons while restoring Th function in noradrenergic and adrenergic cells (Zhou and Palmiter, 1995). DD mice manifest normal dopamine neurons, neuronal connections (Zhou and Palmiter, 1995), and D2 autoreceptors (Paladini et al., 2003). However, DD mice require daily injections of L-3,4-dihydroxyphenylalanine (L-dopa) for survival (Zhou and Palmiter, 1995). Without treatment, DD mice become severely hypophagic and die at $\sim 3$ weeks of age. Systemic treat- 
ment with L-dopa rescues the mouse but produces a transient hyperactive state and induces robust immediate-early gene expression in the striatum (Kim et al., 2000; Chartoff et al., 2001), suggesting that dopamine deficiency results in hypersensitive dopamine receptors. An advantage of the DD mouse model is that, in contrast to lesion models, dopamine neurons are intact, and the ability to restore endogenous dopamine signaling is under experimenter control.

Presynaptic activity was determined by combining multiphoton confocal imaging and destaining of the endocytic tracer FM143. Quantitative immunogold electron microscopy was performed to determine the density of nerve terminal glutamate immunolabeling in corticostriatal terminals. In vivo microdialysis was conducted to measure the extracellular level of basal striatal glutamate. Our data suggest that mice that developed without dopamine possess functional corticostriatal terminals and that acute and chronic dopamine depletion results in hypersensitive presynaptic D2 receptors. Such changes may influence the appearance of dyskinesias in Parkinson's disease and L-doparesponsive dystonia.

\section{Materials and Methods}

Animals. All animal protocols were approved by the University of Washington Animal Care Committee. Control and DD mice were bred as described and maintained on a mixed C57BL/ $6 \times 129 /$ SvEv genetic background (Zhou and Palmiter, 1995). Control mice included wild-type and heterozygous animals that have normal levels of dopamine (Thomas et al., 1998; Rios et al., 1999). DD mice were maintained from $\sim 2$ weeks of age until experimentation by daily injections of L-dopa $(50 \mathrm{mg} / \mathrm{kg}$, i.p.). Mice were anesthetized with ketamine/xylazine before use. Adult DD and control mice used for the experiments were 2-3 months old; 15 -d-old mice [postnatal day 15 (P15)] that had never been exposed to L-dopa and 2 - to 3-month-old adults were used for electron microscopy. Dopaminedepleted recordings were performed at least $24 \mathrm{hr}$ after the last daily $\mathrm{L}$-dopa injection. To restore dopamine in DD mice, $\mathrm{L}-\mathrm{dopa}(50 \mathrm{mg} / \mathrm{kg}$, i.p.) was administered $1 \mathrm{hr}$ before the experiment. To study the effects of acute dopamine depletion, reserpine (methyl reserpate 3,4,5trimethosybenzoic acid ester; Sigma, St. Louis, MO) was dissolved in glacial acetic acid, diluted to a final concentration of $0.1 \%$ acetic acid with distilled water, and injected subcutaneously $(5 \mathrm{mg} / \mathrm{kg})$ at a volume of 20 $\mu \mathrm{l} / \mathrm{gm}$. Control mice received an equal volume of distilled water with $0.1 \%$ acetic acid.

FM1-43 loading and unloading. Coronal striatal sections $(200 \mu \mathrm{m})$ containing the cortex were cut on a vibratome and allowed to recover for $1 \mathrm{hr}$ in carbogenated $\left(95 \% \mathrm{O}_{2} / 5 \% \mathrm{CO}_{2}\right)$ artificial CSF ( $\mathrm{aCSF}$ ) solution (in mm: $109 \mathrm{NaCl}, 5 \mathrm{KCl}, 35 \mathrm{NaHCO}_{3}, 1.25 \mathrm{NaHPO}_{4}, 1.2 \mathrm{MgCl}_{2}, 2 \mathrm{CaCl}_{2}, 10$ D-glucose, and 20 HEPES acid, pH 7.3-7.4, 295-305 mOs) at room temperature. Experiments were performed on the second to fourth frontal slice of caudate-putamen (bregma, +1.54 to $+0.62 \mathrm{~mm}$ ). During experiments, slices were maintained in an RC-27L incubation chamber (56 $\mu \mathrm{l} / \mathrm{mm}$; Warner Instruments, Hamden, CT) perfused at $2 \mathrm{ml} / \mathrm{min}$ with carbogenated aCSF at $37^{\circ} \mathrm{C}$.

FM1-43 (8 $\mu \mathrm{M}$ in aCSF; Molecular Probes, Eugene, OR) was loaded into presynaptic terminals by a $10 \mathrm{~min}$ train of $200 \mu \mathrm{sec}, 400 \mu \mathrm{A}$ pulses at $10 \mathrm{~Hz}$, applied to cortical layers V-VI as described previously (Bamford et al., 2004). For stimulation-dependent corticostriatal terminal loading and unloading, and to elicit dopamine release, pulse trains were applied to the cortex or striatum, respectively, using bipolar twisted tungsten electrodes. Electrical stimulation was provided by a Tektronix R564B wave generator (Tektronixs, Gaithersburg, MD) through a stimulation isolator (AMPI, Jerusalem, Israel) and monitored by a S88 storage oscilloscope (Grass-Telefactor, West Warwick, RI). To remove adventitious tissue staining after FM1-43 loading (Kay et al., 1999), sections were incubated in ADVASEP-7 (AD7; 1 mM in aCSF; CyDex, Overland Park, KS) for 2 min.

During unloading, aCSF was supplemented with AD7 $(100 \mu \mathrm{M})$ and the AMPA receptor blocker 1,2,3,4-tetrahydro-6-nitro-2,3-dioxo-benzo $(f)$ quinoxaline-7-sulfonamide (NBQX; $10 \mu \mathrm{M}$ ) to prevent recurrent endocytosis of dye into terminals and feedback synaptic transmission, respectively. Previous experiments showed that corticostriatal terminal destaining kinetics and terminal responses to synaptic dopamine are independent of postsynaptic NMDA or metabotropic glutamate receptor activation and of muscarinic, nicotinic, and adenosine receptor activity (Bamford et al., 2004). To ensure equilibrium, sections were exposed to pharmacological agents for $10 \mathrm{~min}$ before stimulation-mediated unloading. Drugs were applied to the slice by superfusion. L-Dopa, carbidopa, (+/-)-quinpirole, ( S)-sulpiride, SKF 38393, SCH 23390, cocaine $\mathrm{HCl}$, and $(+)$-amphetamine sulfate were obtained from Sigma. NBQX was from AG Scientific (San Diego, CA).

Imaging. Striatal terminals were visualized in real time using a LSM 510 NLO multiphoton laser scanning confocal microscope (Zeiss, Thornwood, NY) with a titanium-sapphire laser (excitation, $810 \mathrm{~nm}$; emission, $650 \mathrm{~nm}$ ) equipped with a Plan-Neofluar $40 \times / 1.3$ oil objective (Zeiss). Multiphoton microscopy provides excellent three-dimensional spatial resolution in brain slice preparations with minimal photo bleaching and photo damage (Mainen et al., 1999). Images were captured in eight-bit, $123 \times 123 \mu \mathrm{m}$ regions of interest (ROIs) at $512 \times 512$ pixel resolution and acquired at $21.5 \mathrm{sec}$ intervals. The striatal ROI containing fluorescent puncta was $1.5-2.0 \mathrm{~mm}$ distant from the cortical stimulation electrodes. For dopamine-stimulation experiments, bipolar electrodes were placed over the motor striatum and visualized on the edge of the ROI. To compensate for any minor $z$-axis shift, a z-series of five images, separated by 1 $\mu \mathrm{m}$ in the z-plane, was obtained for each period. Images in each z-series were aligned and condensed with maximum transparency.

Data analysis. The time projection of images was analyzed for changes in puncta fluorescence using Image J (Wayne Rosband, National Institutes of Health, Bethesda, MD) and custom-written software in interactive data language (Research Systems, Boulder, CO). The custom software adopts an object recognition protocol that rapidly processes terminal destaining (Zakharenko et al., 2001; Bamford et al., 2004). The software identifies spherical puncta $0.5-1.5 \mu \mathrm{m}$ in diameter that fluoresce 2 SDs above the background. Each puncta is aligned in the $x, y$, and $z$ plane to prevent spatial drift, and the time-dependent fluorescence intensity of each puncta is displayed graphically. Background fluorescence $(<5 \%)$ was subtracted, and the destaining halftime was determined graphically using a software algorithm derived on SigmaPlot software (SPSS, Chicago, IL). Puncta demonstrating no active destaining were rejected. Unless stated otherwise, statistical analysis was performed using the Mann-Whitney $U$ test. For all experiments, $p<0.05$ was considered as a significant difference.

Surgical procedures for microdialysis. DD $(n=9)$ and control $(n=6)$ mice were anesthetized $(10 \mathrm{ml} / \mathrm{kg}$ of $2.5 \%$ ketamine, $1 \%$ xylazine, and $0.5 \%$ acepromazine in normal saline), their heads were shaved, and they were placed in a Cartesian stereotaxic apparatus fitted with a small rodent bite plate. The skin above the skull was cut, and the top of the skull was exposed. A small hole was drilled, and the dura was punctured at the following coordinates from bregma (Franklin and Paxinos, 1997): anterior, $+1.2 \mathrm{~mm}$; lateral, $+1.8 \mathrm{~mm}$. A stainless steel guide cannula (5 mm long, 21 gauge; Small Parts, Miami Lakes, FL) was lowered $1.5 \mathrm{~mm}$ from the surface of the skull. The guide cannula was held in a fixed position by three stainless steel screws attached to the skull and encompassed by cranioplastic (Plastics One, Roanoke, VA). The animals were allowed to recover for 1 week before the start of the microdialysis experiment.

In vivo microdialysis. Dialysis probes were prepared as described previously (Robinson and Whishaw, 1988), with modifications (Meshul et al., 1999). The probes were $210 \mu \mathrm{m}$ in diameter and $2 \mathrm{~mm}$ in length. One day before use, the efficiency of transmitter recovery by the probe was determined by collecting three $10 \mathrm{~min}$ samples (perfusing flow rate of 2 $\mu \mathrm{l} / \mathrm{min})$ after placing the probe in a solution of glutamate $(200 \mathrm{pg} / \mu \mathrm{l})$ in aCSF (in mM: $140 \mathrm{NaCl}, 3.4 \mathrm{KCl}, 1.5 \mathrm{CaCl}_{2}, 1.0 \mathrm{MgCl}_{2}, 1.4 \mathrm{NaH}_{2} \mathrm{PO}_{4}$, and $4.85 \mathrm{NaHPO}_{4}$, $\mathrm{pH}$ 7.4).

After collection of the probe recovery samples and the day before the start of the actual dialysis procedure, the probe was lowered into the guide cannula with the entire length of the dialysis probe in the caudate nucleus. The tip of the guide cannula was positioned at the level above the corpus callosum. The probe was secured to the guide cannula with epoxy. 
The aCSF flowed through the probe overnight at a rate of $0.2 \mu \mathrm{l} / \mathrm{min}$. The following morning, the pump speed was increased to $2 \mu \mathrm{l} / \mathrm{min}$ for $1 \mathrm{hr}$, and then four samples were collected every $15 \mathrm{~min}$ to determine basal extracellular glutamate concentration. We previously verified that changes in the basal extracellular level of striatal glutamate are dependent on the presence of calcium within the aCSF. Replacement of calcium with the divalent chelating agent EGTA and increasing the aCSF concentration of magnesium resulted in a significant decrease in the basal level of glutamate (Meshul et al., 2002). This suggests that at least a portion of the resting level of striatal glutamate is of neuronal origin. The microdialysis sequence was as follows for DD and control mice: four $15 \mathrm{~min}$ baseline samples were collected; saline was injected; two 15 min saline samples were collected; L-dopa ( $50 \mathrm{mg} / \mathrm{kg})$ was injected; eight $15 \mathrm{~min}$ samples were collected; food (Purina 5LJ5) was returned to the dialysis chamber; four $15 \mathrm{~min}$ samples were collected; amphetamine $(5 \mathrm{mg} / \mathrm{kg})$ was injected; four 15 min samples were collected. At the conclusion of the experiment, the animals were perfused with glutaraldehyde fixative (see below), vibratome sections $(100 \mu \mathrm{m})$ were cut and stained with hematoxylin and eosin, and the site of the probe placement within the caudate was verified histologically. Probe placement extended $2 \mathrm{~mm}$ along the central to lateral portion of the striatum. If the placement was not correct (i.e., outside the striatum) or there was extensive damage because of probe insertion, the data from that animal were discarded. The four baseline data points were averaged for each mouse, and the remaining data points were normalized to the baseline value. The saline data points, the $12 \mathrm{~L}$-dopa data points, and the 4 amphetamine data points were averaged separately at each time point, and then means were calculated for each treatment to quantify the effects of saline, L-dopa, and amphetamine on extracellular glutamate levels. The values are expressed as means \pm SEM in picomoles per microliter of dialysate sample. The mean probe recovery ranged between 10 and $15 \%$. For microdialysis, all the data between groups were analyzed using a repeated-measures ANOVA, and significant main effects were further characterized using the Tukey post hoc test for comparison of multiple means.

HPLC detection of dialysate glutamate and dopamine levels. Glutamate concentration in dialysate was determined using a Hewlett-Packard HPLC 1090 interfaced with a Hewlett-Packard 1046A programmable fluorescence detector. Dialysates were derivatized with $o$-phthalaldehyde (OPA) and chromatographed according to a modification of the method of (Schuster, 1988), as reported previously (Meshul et al., 1999, 2002). Dialysates were derivatized by adding $1 \mu \mathrm{l}$ of sample, $5 \mu \mathrm{l}$ of borate buffer, $\mathrm{pH} 10.4$, and $1 \mu \mathrm{l}$ of OPA. The reaction mixture was injected into a reverse-phase C18 column (HP \#79916AA), and OPA derivatives were separated using a linear gradient. Solvent A contained $0.018 \%(\mathrm{v} / \mathrm{v}) \mathrm{TEA}$, $0.3 \%(\mathrm{v} / \mathrm{v})$ tetrahydrofuran, and $20 \mathrm{~mm}$ sodium acetate buffer, $\mathrm{pH}$ 7.2. Solvent B contained 40\% (v/v) acetonitrile, 40\% (v/v) methanol, and $20 \%(\mathrm{v} / \mathrm{v}) 100 \mathrm{~mm}$ sodium acetate, $\mathrm{pH}$ 7.4. The OPA derivatives of glutamate were detected using an excitation wavelength of $340 \mathrm{~nm}$ and an emission wavelength of $450 \mathrm{~nm}$. Assay sensitivity was in the subpicomole range.

Striatal dopamine concentrations were determined by HPLC (Vanderbilt Kennedy Center, Vanderbilt, TN). Each striatum was dissected and homogenized in $100 \mu \mathrm{l}$ of $0.1 \mathrm{M}$ TCA, which contained $10^{-2}$ $\mathrm{M}$ sodium acetate, $10^{-4} \mathrm{M}$ EDTA, $10^{-6} \mathrm{M}$ isoproternol (as internal standard), and $10.5 \%$ methanol, $\mathrm{pH}$ 3.8. The two striata from each mouse were pooled together, and samples were spun in a microcentrifuge at $10,000 \times g$ for $20 \mathrm{~min}$. The supernatant was removed and stored at $-80^{\circ} \mathrm{C}$. Before injection into the HPLC, the supernatant was thawed and centrifuged for $20 \mathrm{~min}$. Biogenic amines were determined by HPLC assay using an Antec Decade (oxidation, 0.7) electrochemical detector. Twenty-microliter samples of the supernatant were injected using a Water $717+$ autosampler onto a Waters Nova-Pak C18 HPLC column $(3.9 \times 300 \mathrm{~mm})$. Biogenic amines were eluted with a mobile phase consisting of $89.5 \% 0.1 \mathrm{M}$ TCA, $10 \mathrm{~mm}$ sodium acetate, $0.1 \mathrm{~mm}$ EDTA, and $10.5 \%$ methanol, $\mathrm{pH} 3.8$. Solvent was delivered at $0.7 \mathrm{ml} / \mathrm{min}$ using a Waters 515 HPLC pump. HPLC control and data acquisition were managed by Millennium 32 software.

Immunogold electron microscopy. DD ( $n=4$ adults; $n=5$ P15) and control ( $n=9$ adults; $n=5$ P15) mice were anesthetized, their chest cavities were opened, and they were perfused transcardially with $3 \mathrm{ml}$ of $1000 \mathrm{U} / \mathrm{ml}$ heparin in $0.1 \mathrm{~m}$ HEPES buffer, $\mathrm{pH} 7.3$, followed immediately by $40 \mathrm{ml}$ of $2.5 \%$ glutaraldehyde $/ 0.5 \%$ paraformaldehyde in $0.1 \mathrm{M}$ HEPES, pH 7.3 , containing $0.1 \%$ picric acid. After the perfusion, the entire brain was then removed and placed in cold $\left(4^{\circ} \mathrm{C}\right)$ fixative overnight. After vibratome sectioning $(200 \mu \mathrm{m})$ and dissection of the left dorsolateral and central caudate (equivalent to $+1.0 \mathrm{~mm}$ anterior to bregma) (Franklin and Paxinos, 1997), the tissue was processed as described previously (Meshul et al., 1994). All tissue from each of the groups was cut and processed on the same day to limit the variables that may occur by cutting and processing tissue on different days.

Post-embedding immunogold electron microscopy was performed according to the method of Phend et al. (1992), as modified by Meshul et al. (1994). The glutamate antibody (non-affinity purified, rabbit polyclonal, G-6642; Sigma), as previously characterized by Hepler et al. (1988), was diluted 1:400,000 in TBS with 0.05\% Tween 20, pH 7.6. Aspartate $(1 \mathrm{~mm})$ was added to the glutamate antibody mixture $24 \mathrm{hr}$ before incubation with the thin-sectioned tissue to prevent any crossreactivity with aspartate within the tissue. Photographs (10/animal) were taken randomly at a final magnification of $40,000 \times$ throughout the neuropil using a digital camera (AMT, Boston, MA). The images were directly captured and stored on the computer by an individual blinded to the experimental groups. The glutamate immunolabeling technique was performed for all of the treatment groups on the same day to limit the variables that may occur by carrying out this procedure on different days.

The number of gold particles per nerve terminal associated with an asymmetrical synaptic contact was counted, and the area of the nerve terminal was determined using Image Pro Plus software (version 3.01; Media Cybernetics, Silver Spring, MD). Glutamate-containing nerve terminals were typically photographed making a synaptic contact on a dendritic spine, indicating that they most likely originated from the motor cortex (Dube et al., 1988; Smith et al., 1994). The gold particles contacting the synaptic vesicles within the nerve terminal were counted and were considered part of the vesicular or neurotransmitter pool as previously established (Meshul et al., 1999). The density of gold particles per square micrometer of nerve terminal area was determined for each animal, and the mean density for each treatment group was calculated (mean density \pm SEM). The differences between treatment groups were analyzed with a one-way ANOVA, and significant main effects were further characterized using the Fisher post hoc test for comparison of multiple means. The specificity of the immunolabeling for the glutamate antibody was previously established by incubating the antibody overnight with $3 \mathrm{~mm}$ glutamate (Meshul et al., 1994). This mixture was then applied to the sections as detailed above, with the final results showing a lack of tissue immunolabeling.

\section{Results}

\section{Loading striatal terminals with FM1-43}

Coronal slices $(200 \mu \mathrm{m})$ encompassing the motor cortex and motor striatum were prepared. When neuronal terminals are stimulated, an action potential occurs that results in endocytosis of FM1-43 dye, which fluoresces after insertion of its hydrophobic tail into the lipid bilayer (Betz and Bewick, 1992; Ryan et al., 1993). With additional stimulation, exocytosis results in subsequent release of the dye from the terminals. The stimulationdependent translocation of the FM1-43 dye into and out of synaptic terminals allows a measure of terminal activity quantified by changes in fluorescence. To ensure specific labeling of corticostriatal terminals, bipolar electrodes were placed over the motor cortex (layers $\mathrm{V}$ and VI) and stimulated for $10 \mathrm{~min}$ in the presence of FM1-43 ( $8 \mu \mathrm{M})$ (Fig. 1 $A, B)$. Although corticostriatal fibers are formed in part by collateral branches from neuronal cell bodies located in cortical layer V (Wilson, 1987; Levesque et al., 1996), most cortical afferents in this slice preparation are probably disconnected from their cell bodies. However, the position of the stimulating electrode was crucial because placement proximal to the cortex (e.g., over the corpus callosum) results in the 


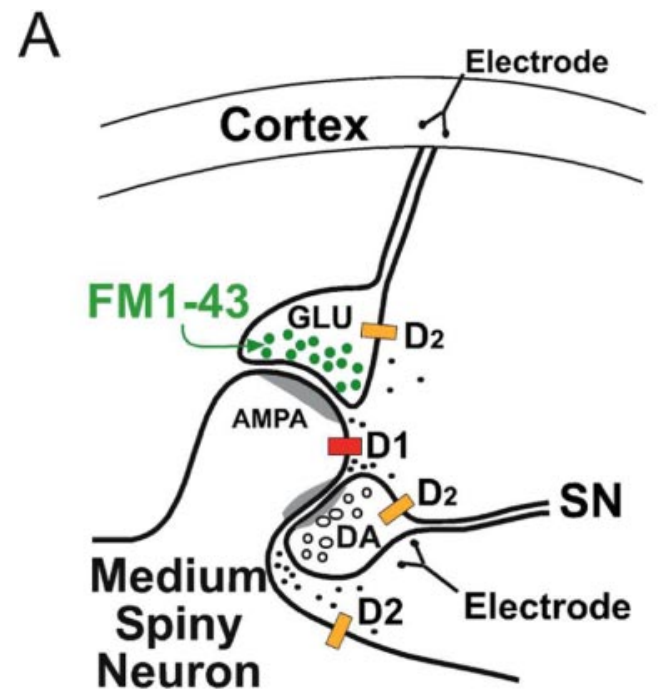

$\mathrm{B}$
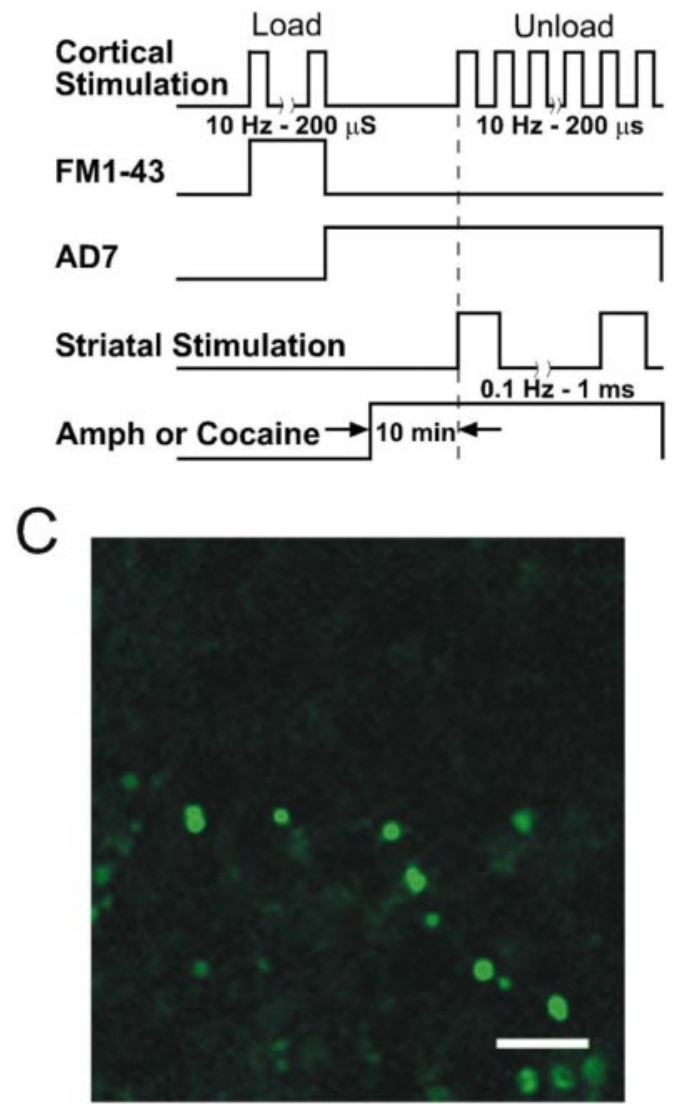

Figure 1. Loading and unloading of corticostriatal terminals with FM1-43. A, The diagram depicts a simplified striatal circuit with a striatal medium spiny neuron (MSN) innervated by an excitatory glutamatergic cortical projection. The MSN is modulated by a dopaminergic projection from the ventral midbrain that stimulates presynaptic and postsynaptic dopamine D2 receptors and postsynaptic D1 receptors. Corticostriatal terminals from the forelimb primary motor cortex are loaded with FM1-43 by bipolar electrode stimulation of cortical layers V-VI. Dopamine is released by stimulating the striatum with a second bipolar electrode. DA, Dopamine; GLU, glutamate; SN, substantia nigra. B, Protocol for determining corticostriatal terminal kinetics. After FM1-43 dye loading, corticostriatal terminals were unloaded by restimulation of the forelimb motor cortex with $200 \mu \mathrm{sec}(400 \mu \mathrm{A})$ pulses. Amphetamine, cocaine, or dopamine receptor agonists were allowed to incubate for 10 min to ensure adequate equilibrium. $C$ A multiphoton image of corticostriatal terminals obtained from the corresponding forelimb motor striatum, located $1.0-1.5 \mathrm{~mm}$ from the site of cortical stimulation, reveals similarly sized puncta arranged in en passant arrays. Scale bar, $5 \mu \mathrm{m}$. release of dopamine from nigrostriatal terminals (Bamford et al., 2004). After exposure to AD7, optical recordings of the motor striatum, located in the dorsolateral quadrant (Brown, 1992), revealed linear en passant arrays of fluorescent puncta characteristic of corticostriatal afferents (Wilson, 1990) (Figs. 1C, 2A).

\section{Stimulation-dependent unloading of FM1-43 from corticostriatal terminals}

After loading, restimulation of the motor cortex resulted in exocytosis of FM1-43 dye from the terminals. Train stimulation resulted in activity-dependent loss of puncta fluorescence decreasing in a manner approximating first-order kinetics characteristic of synaptic vesicle fusion (Ryan et al., 1993) (Fig. 2A-C). Corticostriatal kinetics were determined by measurement of the terminal halftime $\left(t_{1 / 2}\right)$, defined as the time required for terminal fluorescence to decay to half its initial value. Terminal destaining in control slices stimulated at $10 \mathrm{~Hz}\left(t_{1 / 2}=189 \mathrm{sec}\right)$ resulted in an intermediate destaining halftime as reported previously (Bamford et al., 2004); this frequency was used for the remainder of the experiments. The release of FM1-43 from corticostriatal terminals was previously shown to be dependent on the concentration of extracellular calcium and was blocked by cadmium (data not shown), consistent with vesicular exocytosis (Bamford et al., 2004).

\section{D2-like receptor agonists regulate corticostriatal destaining in DD mice}

Previous studies have demonstrated that glutamate release from corticostriatal fibers is dependent on striatal dopamine and may be regulated by $\mathrm{D} 2$ receptors located on corticostriatal terminals (Maura et al., 1988; Garcia-Munoz et al., 1991; Calabresi et al., 1993; O’Donnell and Grace, 1994; Hsu et al., 1995; FloresHernandez et al., 1997; Cepeda et al., 2001; Tang et al., 2001; West et al., 2002; Bamford et al., 2004). To determine whether D2-like receptors regulate corticostriatal activity in DD mice, we examined the effect of the D2-like antagonist sulpiride and the D2-like agonist quinpirole on corticostriatal FM1-43 unloading. Corticostriatal activity in DD mice was determined $24 \mathrm{hr}$ after the last injection of $\mathrm{L}$-dopa when brain dopamine levels were $<1 \%$ of control mice (Table 1) (Zhou and Palmiter, 1995; Szczypka et al., 1999). In control mice, sulpiride (200 nM) caused a slight, but not significant, potentiation of terminal release $\left(t_{1 / 2}=178 \mathrm{sec}\right.$ vs 189 sec, for sulpiride and controls, respectively) (Fig. $3 A, E)(p>$ $0.5)$. Conversely, quinpirole $(1 \mu \mathrm{M})$ inhibited the release of FM143 , as shown by slower destaining $\left(t_{1 / 2}=288 \mathrm{sec} ; p<0.001\right)$. In DD mice, as predicted, sulpiride had no significant effect on corticostriatal release $\left(t_{1 / 2}=212 \mathrm{sec}\right.$ vs $193 \mathrm{sec}$, for sulpiride-treated and untreated DD mice, respectively; $p>0.05$ ), whereas quinpirole produced a pronounced inhibition of terminal activity $\left(t_{1 / 2}=343 \mathrm{sec}\right)($ Fig. $3 B, E)(p<0.001)$. Thus, the release of FM1-43 from corticostriatal terminals in both DD and control mice is consistent with regulation of cortical afferents by D2 receptors (Bamford et al., 2004).

\section{Corticostriatal terminal subtypes}

An advantage of this experimental approach is that we are able to measure the activity of individual terminals, which may permit determination of distinct populations of cortical axon terminals. This is in contrast to postsynaptic recordings of MSNs that integrate currents from many inputs. As suggested by the relatively high variation of destaining puncta arising from a single axon (Fig. $2 B$ ), the data suggest at least two populations of puncta, with effects of D2-like receptor manipulation affecting $\sim 85 \%$ of FM1- 

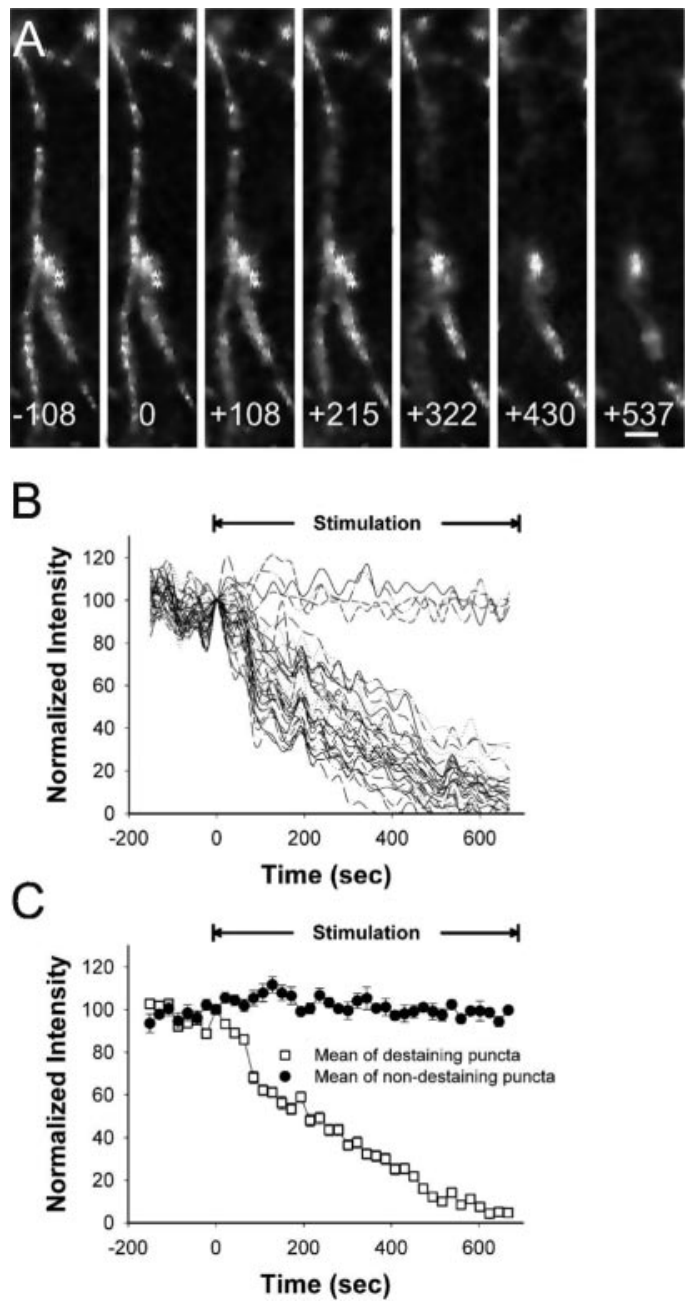

Figure 2. Stimulation-dependent unloading of corticostriatal terminals. A, Multiphoton images captured every 21.5 sec reveal en passant arrays of corticostriatal terminals. Restimulation at $t=0$ with $10 \mathrm{~Hz}$ pulses shows activity-dependent destaining of fluorescent puncta. $B$, Time-intensity analysis of puncta along the axon array shown in $A$ during unloading demonstrates differential rate kinetics $(n=33)$. The plateau lines on the graph represent the fluorescence measurements from non-destaining puncta $(n=4)$. C, Mean fluorescence intensity of destaining and non-destaining puncta shown in $B$ (mean \pm SEM).

43-labeled terminals (Fig. 3C). In control mice, the effect of D2like activation is clearly more profound for terminals that destain more slowly, whereas for DD mice, quinpirole appears to affect most of the terminals, suggesting a loss of terminal segregation in these animals (Fig. 3D).

\section{Corticostriatal D2 receptors are hypersensitive in DD mice} DD mice manifest behavioral and biochemical hypersensitivity to D1 receptor agonists in vivo (Kim et al., 2000). Hypersensitive corticostriatal D2 receptors are also suggested because quinpirole $(1 \mu \mathrm{M})$ inhibits the release of FM1-43 dye from cortical projections in DD mice to a greater extent than in control mice $\left(t_{1 / 2}=\right.$ $343 \mathrm{sec}$ vs $288 \mathrm{sec}$ for DD and control mice, respectively) (Fig. 3E) $(p<0.001)$. To determine the sensitivity of $\mathrm{D} 2$ receptors on corticostriatal terminals in DD and control mice, we exposed striatal slices to incremental concentrations of quinpirole $(0.01-10 \mu \mathrm{M})$ (Fig. 3G). Slices from control mice revealed a dosedependent rise in terminal destaining halftimes with increasing concentrations of quinpirole, reaching a maximum $\left(t_{1 / 2}=351\right.$ sec) at $10 \mu \mathrm{M}$, whereas terminal-destaining halftimes in DD mice
Table 1. Striatal dopamine levels in DD and reserpine-treated mice

\begin{tabular}{lccc}
\hline Animal & Treatment $^{a}$ & DA content (ng/mg protein) & DA percentage \\
\hline $\mathrm{DD}(n=2)$ & L-Dopa & $28.58 \pm 12.4$ & 10.54 \\
$\mathrm{DD}(n=6)$ & Saline & $0.73 \pm 0.19$ & 0.27 \\
Control $(n=4)$ & Reserpine & $1.84 \pm 0.15$ & 0.68 \\
Control $(n=4)$ & Vehicle & $271.07 \pm 26.6$ & 100 \\
\hline
\end{tabular}

Dopamine (DA) concentrations were measured by HPLC. Values are expressed as mean \pm SEM.

${ }^{a}$ Adult DD mice were treated daily with L-dopa $(50 \mathrm{mg} / \mathrm{kg})$. Twenty-three hours after their last treatment, $\mathrm{L}$-dopa or an equivalent volume of saline was administered $1 \mathrm{hr}$ before mice were killed. Control mice received either reserpine $(5 \mathrm{mg} / \mathrm{kg}$, s.c.) or $0.1 \%$ acetic acid in distilled water (vehicle) $13 \mathrm{hr}$ before the experiment.

reached a maximum $\left(t_{1 / 2}=357 \mathrm{sec}\right)$ at $0.1 \mu \mathrm{M}$, consistent with hypersensitive signaling by $\mathrm{D} 2$ receptors on corticostriatal axons.

Next, we examined the effect of D1 receptor manipulation on the release of FM1-43 from corticostriatal terminals. We previously demonstrated that terminal destaining with the D1 receptor agonist SKF 38393 or antagonist SCH 23390 had no effect on control slices (Bamford et al., 2004). In DD mice, terminal kinetics in slices treated with SKF $38393\left(10 \mu \mathrm{M} ; t_{1 / 2}=208 \mathrm{sec} ; n=124\right.$ puncta from four slices $)$ or SCH $23390\left(1 \mu \mathrm{M} ; t_{1 / 2}=204 \mathrm{sec} ; n=\right.$ 68 puncta from four slices) were similar to untreated DD mice $\left(t_{1 / 2}=193 \mathrm{sec} ; n=128\right.$ puncta from seven slices; $\left.p>0.4\right)$, suggesting that in this preparation, corticostriatal terminals are not directly modulated by D1 receptor activation (data not shown).

\section{Stimulation of dopaminergic terminals in DD mice does not affect corticostriatal function}

Local striatal bipolar stimulation at $0.1 \mathrm{~Hz}$ releases dopamine $(\sim 1 \mu \mathrm{M})$ without directly affecting corticostriatal destaining kinetics (Bamford et al., 2004). Conversely, cortical bipolar stimulation triggers no striatal dopamine release, as determined using cyclic voltammetry (Bamford et al., 2004). In slices from control mice, striatal stimulation depressed the release of FM1-43 from corticostriatal terminals $\left(t_{1 / 2}=276 \mathrm{sec}\right.$ for stimulated dopamine release vs $189 \mathrm{sec}$ for controls) (Fig. $4 A)(p<0.001)$. The effect was similar to that seen with the D2 receptor agonist quinpirole $\left(t_{1 / 2}=288 \mathrm{sec}\right)$ and was reversed by the $\mathrm{D} 2$ receptor antagonist sulpiride $\left(t_{1 / 2}=191 \mathrm{sec} ; p>0.8\right)$. Striatal stimulation did not alter terminal destaining times in slices from DD mice $\left(t_{1 / 2}=201\right.$ sec vs $193 \mathrm{sec}$ for nonstimulated DD mice) (Fig. 4C) ( $p>0.5)$, as expected, because dopamine content is $<1 \%$ of control levels (Table 1) (Szczypka et al., 1999).

To provoke the release of dopamine in a different way, striatal slices were incubated in amphetamine, which releases dopamine through reverse transport (Jones et al., 1998; Schmitz et al., 2001). In control mice, amphetamine $(10 \mu \mathrm{M})$ significantly slowed corticostriatal terminal destaining $\left(t_{1 / 2}=266 \mathrm{sec}\right.$ for amphetamine vs $189 \mathrm{sec}$ for controls) (Fig. $4 A, D)(p<0.001)$. The effect was blocked by sulpiride $\left(t_{1 / 2}=187 \mathrm{sec} ; p>0.8\right)$. Cocaine $(20 \mu \mathrm{M})$, which elevates synaptic dopamine by blocking reuptake (Williams and Lacey, 1988; Koob, 1992), also slowed corticostriatal destaining in slices from control mice when combined with striatal stimulation $\left(t_{1 / 2}=241 \mathrm{sec}\right)$ (Fig. $\left.4 B\right)(p<0.001)$. As expected, cocaine had no effect in the absence of stimulated dopamine release $\left(t_{1 / 2}=186 \mathrm{sec} ; p>0.7\right)$. In contrast, in slices from DD mice, there was no significant effect of amphetamine $\left(t_{1 / 2}=\right.$ $218 \mathrm{sec}$ for amphetamine vs $193 \mathrm{sec}$ for untreated DD mice) (Fig. $4 C, D)(p>0.05)$ or cocaine with concurrent striatal stimulation $\left(t_{1 / 2}=217 \mathrm{sec} ; p>0.05\right)$, suggesting ineffectual release of dopamine in response to behaviorally relevant stimulation (Williams and Lacey, 1988; D. L. Robinson et al., 2001). 

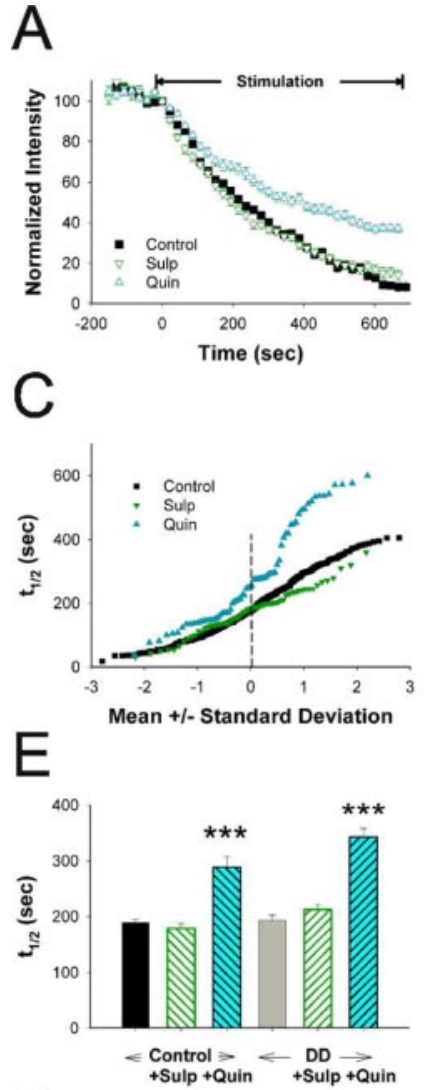

G

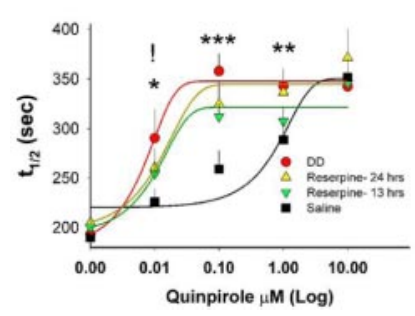

Figure 3. Effects of $D 2$ receptor manipulation on corticostriatal terminals from $D D$ and reserpine-treated mice. $A$, Decay of FM1-43 fluorescence intensity with $10 \mathrm{~Hz}$ cortical stimulation from control animals treated with the D2-like receptor antagonist sulpiride (Sulp; $10 \mu \mathrm{m}$; $\nabla$ ) and the D2-like agonist quinpirole (Quin; $0.5 \mu \mathrm{m} ; \triangle$ ) are compared with untreated sections (ם). B, FM1-43 fluorescence in slices from DD animals exposed to Sulp and Quin show similar responses to controls. C, Normal probability curves of individual terminal halftimes shown in $A$. The $x$-axis indicates the SD from the mean value. When plotted in this manner, normally distributed data yield a straight line (Van der Kloot, 1991; Sulzer and Pothos, 2000; Bamford et al., 2004). The destaining kinetics for Quin-treated sections reveal at least two terminal subpopulations, which begin to deviate $\sim 0.5 \mathrm{SD}$ s below the mean values. D, Normal probability plots of individual terminal halftimes in $D D$ mice from $B$. Subpopulations of terminals from $D D$ mice are less apparent than in control mice (compare $C, D$ ). $E$, Mean terminal destaining halftimes for experiments shown in $A$ and $B$. Terminal halftimes from control slices treated with the Sulp ( $n=67$ puncta; 4 slices) and Quin ( $n=77$ puncta; 3 slices) are compared with untreated control slices ( $n=381$ puncta; 18 slices) and with terminal halftimes from DD slices $(n=128$ puncta; 7 slices) exposed to Sulp ( $n=85$ puncta; 4 slices) or Quin ( $n=94$ puncta; 4 slices). ${ }^{* * *} p<0.001$ compared with control. F, Normal probability plots of individual terminal responses in slices from reserpine-treated mice demonstrate loss of terminal subpopulations after incubation in Quin. $G$, Concentration curves of corticostriatal terminal halftimes from control sections treated with Quin at $0 \mu \mathrm{M}(n=188$ puncta; 10 slices), $0.01 \mu \mathrm{M}$ ( $n=80$ puncta; 2 slices), $0.1 \mu \mathrm{M}$ ( $n=55$ puncta; 2 slices), $1 \mu \mathrm{m}$ ( $n=77$ puncta; 3 slices), and $10 \mu \mathrm{M}$ ( $n=63$ puncta; 2 slices) are compared with sections from DD mice exposed to similar concentrations of Quin at $0 \mu \mathrm{M}$ ( $n=128$ puncta; 7 slices), $0.01 \mu \mathrm{m}(n=24$ puncta; 2 slices), $0.1 \mu \mathrm{M}$ ( $n=59$ puncta; 2 slices), $1 \mu \mathrm{m}$ ( $n=94$ puncta; 4 slices), and $10 \mu \mathrm{m}$ ( $n=38$ puncta; 2 slices) and to sections from reserpine-treated mice killed at $13 \mathrm{hr}$ [Quin at $0 \mu \mathrm{m}$ ( $n=83$ puncta; 4 slices), 0.01 $\mu \mathrm{M}(n=65$ puncta; 4 slices), $0.1 \mu \mathrm{m}$ ( $n=93$ puncta; 3 slices $), 1 \mu \mathrm{M}$ ( $n=60$ puncta; 3 slices),
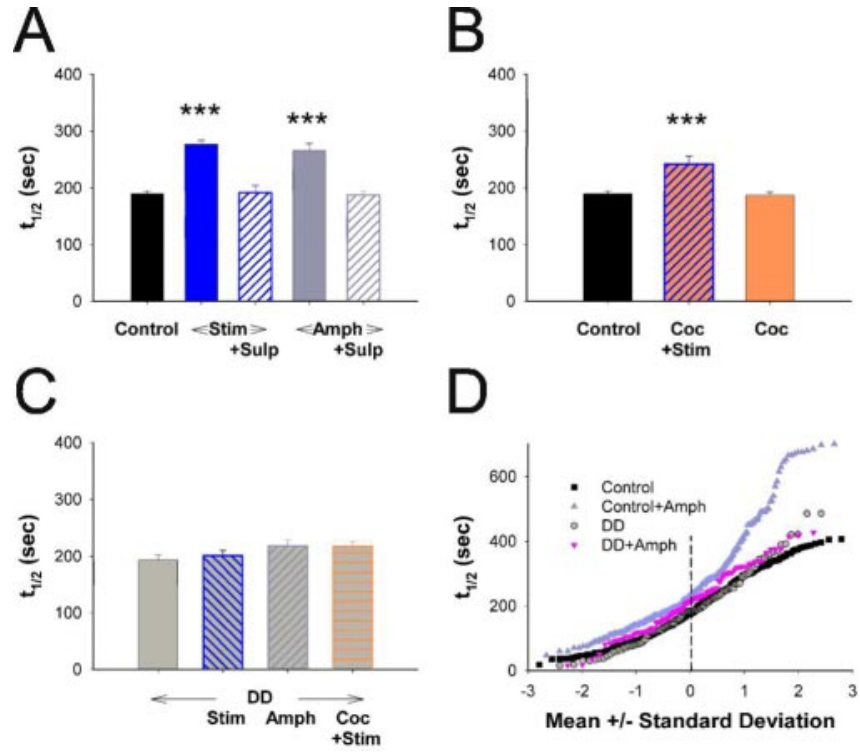

Figure 4. Corticostriatal terminals from DD mice do not respond to stimulated release of dopamine. $A$, Corticostriatal terminal halftimes $\left(t_{1 / 2}\right)$ from control mice. Compared with untreated sections (Control; $n=381$ puncta; 18 slices), synaptic dopamine released by bipolar striatal stimulation at $0.1 \mathrm{~Hz}$ (Stim; $n=391$ puncta; 12 slices) or by amphetamine (Amph; $n=$ 132 puncta; 6 slices) slowed FM1-43 dye release from corticostriatal terminals. Sulpiride (Sulp) occluded the response to striatal stimulation ( $n=49$ puncta; 4 slices) and to Amph $(n=95$ puncta; 5 slices). ${ }^{* * *} p<0.001$ compared with control. $B$, Cocaine with dopamine-releasing striatal stimulation (Coc + Stim; $n=70$ puncta; 5 slices) also increased corticostriatal terminal halftimes, whereas Coc without striatal stimulation did not ( $n=139$ puncta; 3 slices). ${ }^{* * *} p<0.001$ compared with control. C, For DD mice, corticostriatal terminal halftimes in sections with striatal stimulation ( $n=108$ puncta; 4 slices) or after treatment with Amph ( $n=87$ puncta; 6 slices) or with Coc combined with dopamine-releasing striatal stimulation ( $n=119$ puncta; 6 slices) show no change compared with untreated DD sections ( $n=128$ puncta; 7 slices). D, Normal probability plot of individual terminal halftimes for control and DD sections exposed to Amph.

\section{L-Dopa restores corticostriatal terminal activity}

Systemic L-dopa (50 mg/kg, i.p.) partially restores brain dopamine to $\sim 10 \%$ of normal (Table 1) (Szczypka et al., 1999). L-Dopa treatment, $1 \mathrm{hr}$ before the experiment, increased corticostriatal terminal halftimes in slices from DD mice $\left(t_{1 / 2}=271 \mathrm{sec}\right.$ vs $193 \mathrm{sec}$ for L-dopa- and saline-treated DD mice, respectively) (Fig. 5A, $B)(p<0.001)$. The effect of L-dopa on slices from DD mice was partially reduced by adding the potent L-aromatic amino acid decarboxylase (L-AADC) inhibitor carbidopa (300 $\mu \mathrm{M})$ to the slice $\left(t_{1 / 2}=233 \mathrm{sec} ; p<0.001\right.$ compared with L-dopatreated DD mice) and was occluded by sulpiride $\left(t_{1 / 2}=187 \mathrm{sec}\right.$; $p>0.5$ compared with saline-treated DD mice) (Fig. $5 B$ ). Control mice treated with L-dopa also demonstrated a depression in terminal destaining times $\left(t_{1 / 2}=214 \mathrm{sec} ; n=216\right.$ puncta from eight slices vs $193 \mathrm{sec}$ for L-dopa- and saline-treated controls, respectively; $p<0.01)$ that was reversed by the addition of sulpiride $\left(t_{1 / 2}=196 \mathrm{sec} ; n=96\right.$ puncta from five slices; data not shown; $p>0.1)$.

In L-dopa-treated DD mice, endogenous dopamine, released by either striatal stimulation $\left(t_{1 / 2}=331 ; p<0.01\right.$ compared with

and $10 \mu \mathrm{M}$ ( $n=112$ puncta; 4 slices)] and $24 \mathrm{hr}$ [Quin at $0 \mu \mathrm{M}$ ( $n=70$ puncta; 3 slices), 0.01 $\mu \mathrm{M}$ ( $n=35$ puncta; 2 slices), $0.1 \mu \mathrm{M}$ ( $n=57$ puncta; 3 slices), $1 \mu \mathrm{M}$ ( $n=45$ puncta; 2 slices), and $10 \mu \mathrm{M}(n=33$ puncta; 3 slices $)$. $p<0.01$ for interaction between controls and DD or reserpine-treated mice; two-way ANOVA. ${ }^{*} p<0.05$; ${ }^{* *} p<0.01$; ${ }^{* * *} p<0.001$ for DD mice and $p<0.05$ for reserpine-treated mice compared with similarly treated sections from control mice. The data were fit using a three-parameter sigmoidal equation (SigmaPlot). 
A

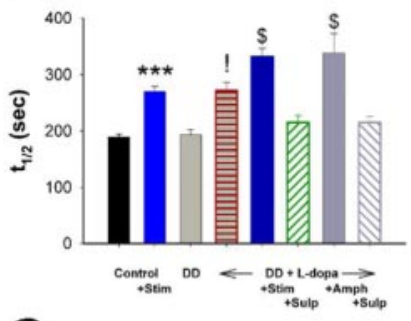

C

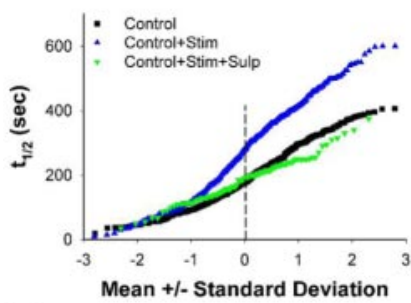

E
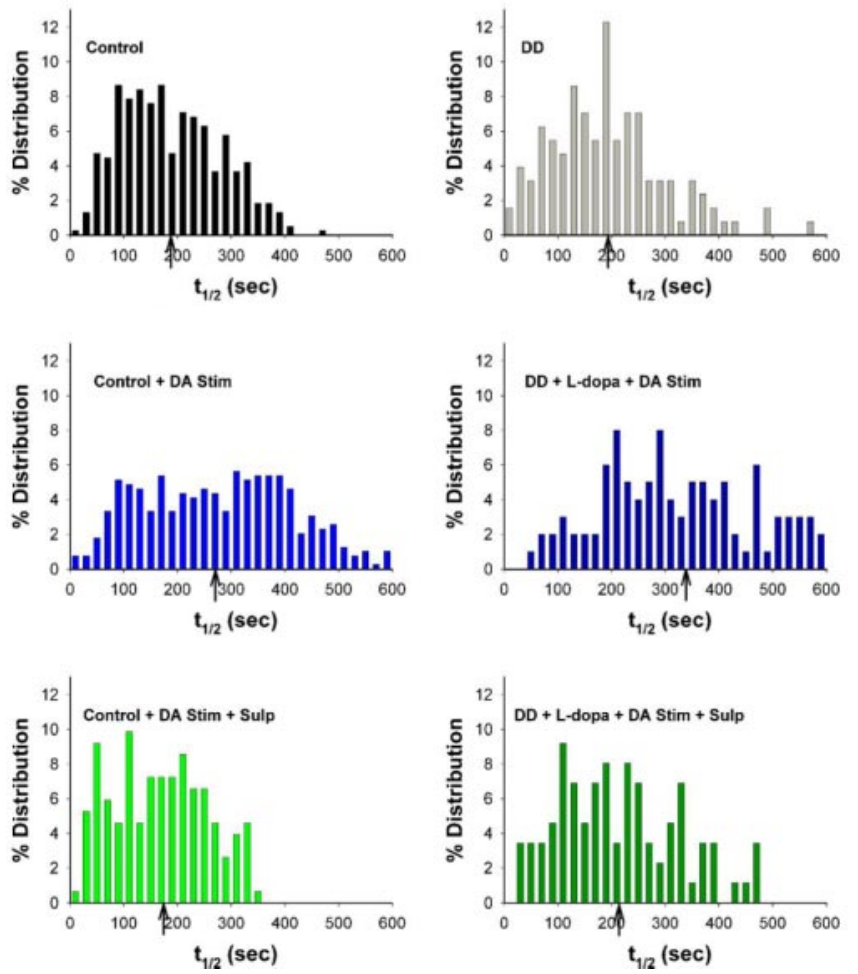

Figure 5. L-Dopa restores corticostriatal responses to dopamine in DD mice. $A$, Corticostriatal halftimes for control mice with (Stim; $n=256$ puncta; 7 slices) and without ( $n=381$ puncta; 18 slices) striatal stimulation are compared with DD mice ( $n=128$ puncta; 7 slices). DD mice treated with L-dopa ( $n=107$ puncta; 4 slices) demonstrate elevated halftimes of destaining, which increase further with striatal stimulation (Stim; $n=104$ puncta; 4 slices) or amphetamine (Amph; $n=77$ puncta; 4 slices). Sulpiride (Sulp) occludes the effect of $\mathrm{L}$-dopa combined with stimulated dopamine ( $n=87$ puncta; 4 slices) or Amph ( $n=92$ puncta; 5 slices). ${ }^{* * *} p<0.001$ compared with control; $! p<0.001$ compared with sections from untreated DD mice; $\$ p<0.01$ compared with DD mice treated with L-dopa. $B$, Normal probability plots of individual terminal halftimes for DD mice with and without L-dopa (from $A$ ) are compared with slices from L-dopa-treated DD mice that were exposed to carbidopa ( $n=110$ puncta; 4 slices) and Sulp ( $n=114$ puncta; 4 slices). C, Normal probability plots of individual terminal halftimes $(A)$ for control mice demonstrate that stimulated dopamine shifts $\sim 85 \%$ of the slower destaining terminals to a lower rate of destaining. Sulp occludes the effect of released dopamine. $D$, Normal probability plots of terminal halftimes from DD slices are compared with dopamine-stimulated (Stim) sections from L-dopa-treated DD mice with and without Sulp. $E$, Histograms show distributions of corticostriatal destaining times from control and DD slices shown in Cand D. After cortical stimulation, the mean terminal destaining times for control and DD terminals is
L-dopa-treated DD mice) or amphetamine $\left(t_{1 / 2}=338 \mathrm{sec} ; p<\right.$ $0.001)$ resulted in additional depression of FM1-43 dye release (Fig. $5 A, D, E$ ) to a much greater extent than that seen in similarly treated control mice $\left(t_{1 / 2}=276 \mathrm{sec} ; p<0.003\right)$ (Fig. $\left.5 A, C, E\right)$. Striatal stimulation slowed the destaining of the majority of terminals in L-dopa-treated DD mice but affected only the slowest destaining terminals $(\sim 85 \%)$ in controls (Fig. 5, compare $C, D$ ). Similar to controls (Figs. $4 A, 5 C$ ), sulpiride reversed the effect of amphetamine $\left(t_{1 / 2}=215 \mathrm{sec}\right.$ vs $207 \mathrm{sec}$ for untreated DD mice; $p>0.05)$ and stimulated dopamine release $\left(t_{1 / 2}=214 \mathrm{sec} ; p>\right.$ 0.1 compared with untreated DD mice) in L-dopa-treated DD mice (Fig. $5 A, D, E$ ), shifting the population of terminals toward faster destaining halftimes (Fig. $5 E$ ). Thus, after the administration of L-dopa, amphetamine increases synaptic dopamine reducing FM1-43 release from corticostriatal terminals possessing hypersensitive D2 receptors.

Finally, we accessed the possibility of D1 receptor-mediated corticostriatal activation in dopamine-restored DD mice. SKF 38393 did not significantly alter destaining from L-dopa-treated DD mice with striatal stimulation $\left(t_{1 / 2}=372 \mathrm{sec}, n=62\right.$ puncta from three slices for SKF 38393-treated slices vs $t_{1 / 2}=331 \mathrm{sec}$, $n=104$ puncta from four slices; data not shown; $p>0.05$ ). Likewise, SCH 23390 did not change terminal destaining halftimes $\left(t_{1 / 2}=302 \mathrm{sec} ; n=93\right.$ puncta from four slices; $\left.p>0.1\right)$. Interestingly, corticostriatal destaining times in the presence of SKF 38393 were significantly slower than those treated with SCH 23390 ( $p=0.002$ ). This suggests that dopamine-stimulated postsynaptic D1 receptors may also act indirectly to depress cortical afferents, an effect not previously seen in control mice (Bamford et al., 2004).

\section{Acute dopamine depletion with reserpine results in early changes in $\mathrm{D} 2$ receptor sensitivity}

To analyze the effect of acute dopamine depletion on corticostriatal terminals, control mice were treated with reserpine $(5 \mathrm{mg} /$ $\mathrm{kg}$, s.c.) or vehicle and killed after 13 and $24 \mathrm{hr}$. Reserpine-treated animals rapidly became docile with little voluntary movement. At $13 \mathrm{hr}$, striatal dopamine fell to $<1 \%$ of normal, as measured by HPLC (Table 1). Corticostriatal destaining halftimes in slices from reserpine-treated mice $\left(t_{1 / 2}=200 \mathrm{sec}\right)$ did not differ from controls $\left(t_{1 / 2}=203 \mathrm{sec} ; n=188\right.$ puncta from five slices; $\left.p>0.8\right)$ and did not respond to amphetamine $\left(t_{1 / 2}=188 \mathrm{sec} ; n=129\right.$ puncta from four slices; $10 \mu \mathrm{M} ; p>0.2)$ or sulpiride $\left(t_{1 / 2}=196\right.$ sec; $n=125$ puncta from three slices; $10 \mu \mathrm{M}$; data not shown; $p>$ 0.7 ) (Fig. $3 F)$. Quinpirole $(0.1 \mu \mathrm{M})$ depressed the release of FM1-43 to a greater degree in slices from reserpine-treated mice $\left(t_{1 / 2}=311 \mathrm{sec}\right)$ than in controls $(269 \mathrm{sec} ; p<0.05)$ and affected most of the terminals, suggesting an early loss in terminal segregation (Fig. $3 F$ ). Concentration curves for quinpirole at 13 and $24 \mathrm{hr}$ after reserpine treatment demonstrate a time-dependent increase in destaining halftimes, suggesting that acute depletion of dopamine results in early changes in D2 receptor sensitivity (Fig. 3G).

\section{Electron microscopic glutamate immunolabeling}

DD mice develop without dopamine until about P15 and exist in the dopamine-depleted state for 15-18 hr each day there-

$\leftarrow$

$\sim 200 \mathrm{sec}$ (top). Both populations shift to longer destaining times ( $\sim 300 \mathrm{sec}$ ) when dopamine is released via striatal stimulation (middle). The effect of dopamine is attenuated by Sulp (bottom). Arrows indicate mean values that shift to the right (slower destaining) with dopamine release and normalize after incubation with Sulp. 
after. This perturbation of the dopaminergic system may affect basal striatal glutamatergic tone and may account for some of the observed differences in corticostriatal function. To address this possibility, quantitative immunogold electron microscopy was conducted to determine whether the density of glutamate immunolabeling associated with synaptic vesicles (i.e., neurotransmitter pool) in nerve terminals making an asymmetrical synaptic contact onto dendritic spines was normal in adult DD mice compared with their littermate controls. We also examined striatal sections from P15 DD mice that had never been exposed to dopamine (and their control littermates). An example of nerve terminal glutamate immunolabeling in each of the four groups is illustrated in Figure 6. There is a higher density of gold labeling within the nerve terminal compared with the adjacent dendritic spine, illustrating the specificity of the technique. There was no difference in the density of nerve terminal glutamate immunoreactivity within the striatum between any of the groups ( $p>0.5$; ANOVA) (Table 2). Normal cytoarchitecture was evident; no differences were found between genotypes in the percentage of nerve terminals making contact with the shaft of dendrites (verses the head of the spine), the percentage of all asymmetrical synaptic contacts containing a perforated postsynaptic density, or the
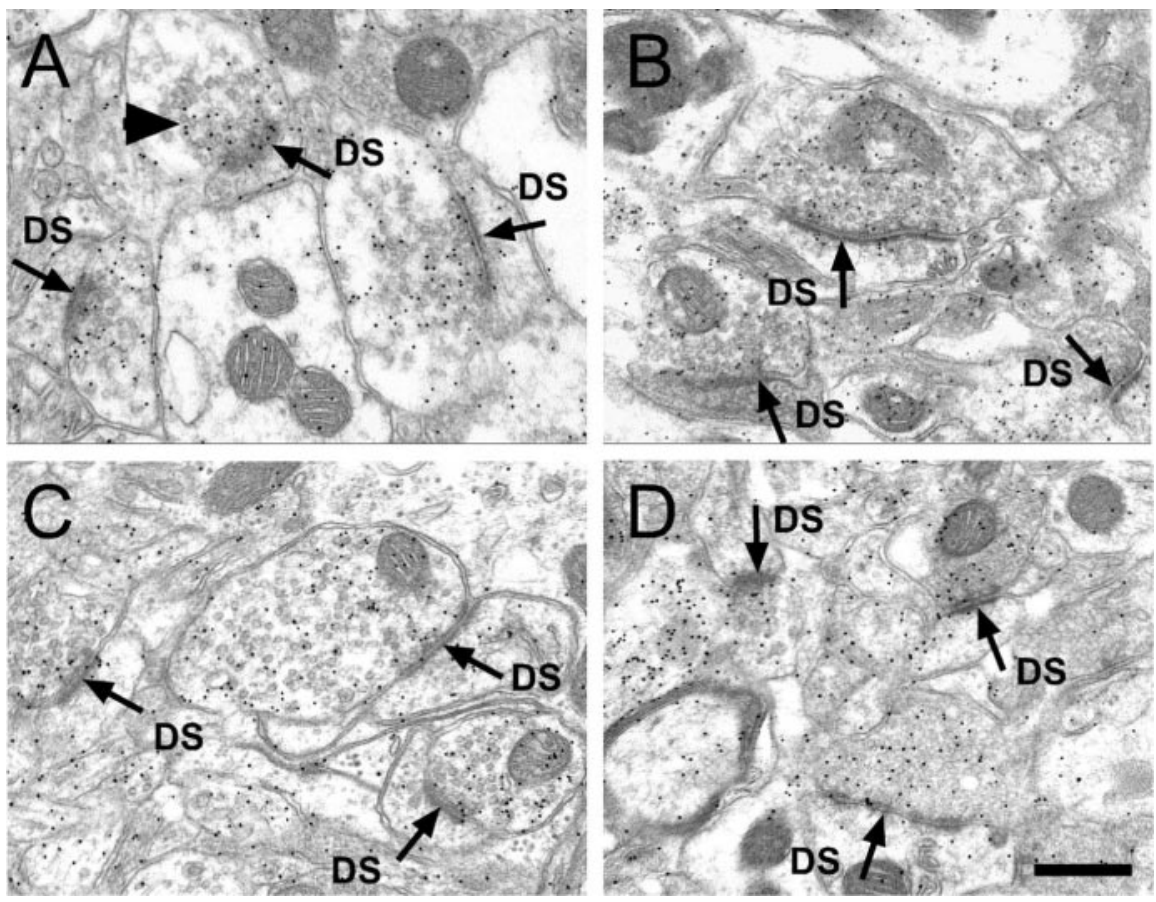

Figure 6. Electron photomicrographs using the immunogold technique to localize an antibody against the neurotransmitter glutamate within the dorsolateral striatum. $A$, Control adult. Three nerve terminals are seen making an asymmetrical synaptic contact (arrows) with an underlying dendritic spine (DS). Within the nerve terminal are numerous $10 \mathrm{~nm}$ gold particles (arrowhead), indicating the location of the antibody. These gold particles are found overlying round synaptic vesicles. Note the large number of gold particles located within the nerve terminal compared with the underlying dendritic spine. $B, D D$ adult. Note that the density of nerve terminal glutamate immunolabeling appears similar to that seen in the control adult group in $A$. C, Control P15. The overall morphology and the density of nerve terminal immunogold labeling appear similar to that found in the adult control and adult DD groups. D, DD P15. Although these mice were never exposed to L-dopa, the overall morphology and density of nerve terminal glutamate immunolabeling are similar to all the groups represented in $A-C$. Scale bar, $0.50 \mu \mathrm{m}$. No significant differences were found between groups.

percentage of all asymmetrical synaptic

contacts, the terminals of which were making multiple contacts onto dendritic spines (i.e., multiple synaptic boutons) (Table 2). These last two measurements have been suggested to be indicative of increased synaptic activity (Greenough et al., 1978; Harris, 1995). These data suggest that dopamine is not required for normal development of synapses by either dopaminergic or corticostriatal processes onto MSN dendrites. These specialized synaptic structures are maintained into adulthood with exposure to dopamine for only a few hours each day.

It is possible that there exist morphological changes in the corticostriatal glutamatergic system in DD mice that were undetected by the methods used here (but may be detectable by stereological synaptic counts), however, there were no changes in the percentage of asymmetrical synaptic contacts on dendritic shafts, perforated synapses, or the percentage of multiple synaptic boutons between genotypes, suggesting that there were no gross changes in synaptic organization.

\section{Microdialysis}

Microdialysis was conducted as an additional measure of basal striatal glutamate levels. After collecting four 15 min baseline samples, nine DD and six control mice were given injections of vehicle (PBS with ascorbic acid), and two 15 min samples were collected. L-Dopa $(50 \mathrm{mg} / \mathrm{kg}$ ) was then administered to all mice, and 1215 min samples were collected. Finally, amphetamine (5.0 $\mathrm{mg} / \mathrm{kg}$ ) was injected, and four 15 min samples were collected. Three mice were removed from the study because the probes loosened from the guide cannula overnight. Two animals were removed because of incorrect probe placement. Thus, data from six DD and four control mice are reported here. Figure 7 shows that the basal extracellular level of glutamate within the dialysate samples was not different between control and DD mice (Fig. 7A, inset). In addition, neither saline nor L-dopa treatment changed extracellular glutamate in either genotype. In contrast, amphetamine treatment decreased extracellular glutamate in control mice $(p<0.05)$ but was without effect in DD mice $(p>0.5$; repeated-measures ANOVA). Locomotor behavior was monitored throughout the experiment to confirm adequate drug delivery (Fig. 7C). L-Dopa treatment induced locomotion in DD mice that was suppressed by subsequent amphetamine treatment (because of stereotypy), whereas locomotion by control mice was unaffected by L-dopa treatment and stimulated by amphetamine. Combined with the electron microscopy results, these data suggest that both intracellular (i.e., nerve terminal) and extracellular (dialysis) basal glutamate levels are normal in DD mice.

\section{Discussion}

We adapted multiphoton confocal microscopy and destaining of the endocytic tracer FM1-43 to measure corticostriatal terminal activity in DD and reserpine-treated mice. By identifying an intact corticostriatal projection in a slice preparation, this technique has provided the first direct observation of corticostriatal terminal activity with dopamine deficiency. Targeting corticostriatal neurons while loading and unloading FM1-43 ensured the specific identification of labeled terminals. We previously demonstrated that the destaining of FM1-43 from terminals was at- 
Table 2. Corticostriatal cytoarchitecture in DD and control mice

\begin{tabular}{|c|c|c|c|c|}
\hline & $\begin{array}{l}\text { Control } \\
\text { adult }\end{array}$ & $\begin{array}{l}\text { DD } \\
\text { adult }\end{array}$ & $\begin{array}{l}\text { Control } \\
\text { pup (P15) }\end{array}$ & $\begin{array}{l}\text { DD } \\
\text { pup (P15) }\end{array}$ \\
\hline Number of mice & 9 & 4 & 5 & 5 \\
\hline $\begin{array}{l}\text { Number of synapses analyzed } \\
\text { Glutamate density (gold particles } / \mu \mathrm{m}^{2}\end{array}$ & 272 & 118 & 194 & 163 \\
\hline within a terminal) & $92.6 \pm 8.5$ & $88.6 \pm 5.9$ & $75.6 \pm 5.4$ & $89.2 \pm 11.0$ \\
\hline Properties of asymmetrical synapses & & & & \\
\hline $\begin{array}{l}\text { Percentage of synapses with contacts on } \\
\text { dendritic shafts }\end{array}$ & $\begin{array}{l}4.7 \pm 1.4 \\
9.8+20\end{array}$ & $\begin{array}{l}11.4 \pm 4.0 \\
14.1+14\end{array}$ & $\begin{array}{l}5.8 \pm 1.4 \\
78+20\end{array}$ & $\begin{array}{l}8.0 \pm 1.6 \\
56+34\end{array}$ \\
\hline $\begin{array}{l}\text { Percentage of synapses with perforations } \\
\text { Percentage of synapses with multiple }\end{array}$ & $9.8 \pm 2.0$ & $14.1 \pm 1.4$ & $7.8 \pm 2.0$ & $5.6 \pm 3.4$ \\
\hline contacts/terminal & $3.3 \pm 1.7$ & $5.1 \pm 2.0$ & $4.1 \pm 2.1$ & $2.3 \pm 1.0$ \\
\hline
\end{tabular}

Data are expressed as mean \pm SEM.
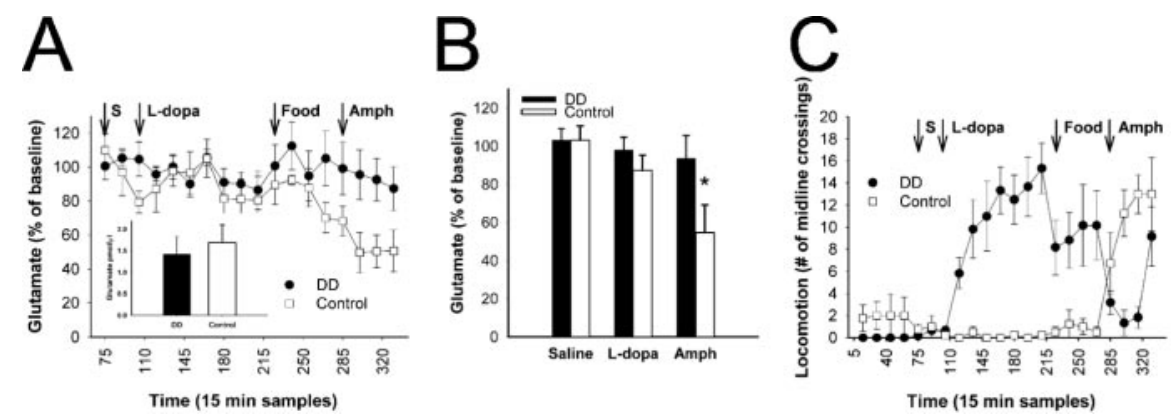

Figure 7. Microdialysis in DD and control mice. A, Saline (S) and L-dopa (50 mg/kg) treatment do not alter extracellular glutamate concentration in either genotype. In contrast, amphetamine (Amph; $5 \mathrm{mg} / \mathrm{kg}$, i.p.) decreased the extracellular concentration of glutamate in control mice $(n=4)$ but not in DD mice $(n=6)$. Arrows denote systemic drug treatment. Inset, Basal extracellular level of striatal glutamate within the dialysate sample as expressed in picomoles per microliter for each genotype. $B$, Pooled data from $A$ quantifying the response to drug treatment. ${ }^{*} p<0.05$. C, Locomotor behavior during microdialysis. Each data point reflects that average number of midline crossings during a $60 \mathrm{sec}$ interval (collected every $15 \mathrm{~min}$ ).

tributable to stimulation-dependent synaptic vesicle exocytosis, as shown by the dependence on extracellular calcium and its blockade by cadmium, the increase in response magnitude as a function of stimulation frequency, and the display of first-order kinetics characteristic of synaptic vesicle fusion (Bamford et al., 2004).

Corticostriatal responses from DD mice treated with a D2 receptor agonist or antagonist suggest that dopamine signaling during development is not necessary for functional corticostriatal D2 receptors in adulthood. This is consistent with previous studies demonstrating normal connectivity of dopamine neurons (Zhou and Palmiter, 1995), normal expression of D1 and D2 receptors (Kim et al., 2000), and normal D2 autoreceptor function (Paladini et al., 2003) in the absence of dopamine. Corticostriatal terminals in DD mice did not respond to the stimulated release of synaptic dopamine or to pharmacological release with amphetamine or cocaine in physiological relevant concentrations. This is expected because dopamine levels in DD mice are $<1 \%$ of normal (Zhou and Palmiter, 1995).

Treatment of DD mice with systemic L-dopa restored the effect of stimulated dopamine release and amphetamine on corticostriatal kinetics. One hour after the systemic administration of L-dopa, corticostriatal terminal destaining halftimes in DD mice were depressed by $40 \%$ compared with saline-treated DD mice. This is consistent with the 10 -fold increase in brain dopamine levels that follows L-dopa administration (Szczypka et al., 1999). The release of synaptic dopamine, provoked by either striatal stimulation or by exposure to amphetamine resulted in an additional 25\% depression of corticostriatal activity.

Similar to observations in DD mice, corticostriatal responses in slices from reserpine-treated mice were normal after the acute depletion of vesicular dopamine but, unlike controls, were unchanged when exposed to amphetamine. The absence of detectable effects of amphetamine after reserpine has been demonstrated previously (Calabresi et al., 1988; Sulzer et al., 1996), but not in some in vivo studies (Niddam et al., 1985; Callaway et al., 1989), suggesting that under specific conditions (Florin et al., 1995), activation of Th by reserpine (Pasinetti et al., 1990) increases cytosolic dopamine (Larsen et al., 2002), which can then be released by amphetamine.

The lack of endogenous dopamine results in corticostriatal D2 hypersensitivity. This was evident by (1) a greater sensitivity to the D2 agonist quinpirole in DD and reserpine-treated mice; (2) by the apparent loss of corticostriatal terminal segregation, in which the faster destaining terminals responded to dopamine in DD and reserpine-treated mice but not in control mice; and (3) the amplified response to psychostimulants in DD mice after dopamine repletion. Because steadystate expression of the total population of D2 receptors is normal in DD mice (Kim et al., 2000), it is likely that the observable changes reflect alterations in D2 receptor desensitization (Ito et al., 1999). Increases in D2 receptor sensitivity after dopamine depletion (Burt et al., 1977; Schultz, 1982; Arnt, 1985; Traub et al., 1986) occur rapidly (Calabresi et al., 1988; LaHoste and Marshall, 1994) and have been linked to changes in mRNA (Jaber et al., 1992). Alternative considerations include alterations of the PLC $\beta 1$-signaling cascade (Hernandez-Lopez et al., 2000), changes in $c$-fos expression (Paul et al., 1992; LaHoste et al., 1993), or an increase in D2 receptor abundance on the cortical axons.

Although the response of individual corticostriatal synaptic terminals appears to fall into multiple categories, the significance of these subpopulations is not clear. It may be that subpopulations of corticostriatal terminals express different receptors, as suggested by electrophysiological (Flores-Hernandez et al., 1997; Akopian and Walsh, 2002; Bamford et al., 2004) or ultrastructural immunocytochemical studies (Wang and Pickel, 2002). Corticostriatal terminals in control mice appear to be segregated into two groups based on their response to dopamine, with slower destaining terminals $(\sim 85 \%)$ responding to dopamine by an additional reduction in activity. In DD mice, terminal subpopulations are not readily apparent because most of the termi- 
nals show depression of destaining in response to D2 receptor activation, an effect likely mediated by D2 receptor hypersensitivity. This is consistent with the findings that corticostriatal transmission is not consistently inhibited by dopamine or D2 receptor activation unless animals have been treated with neuroleptics (Calabresi et al., 1992) or 6-hydroxydopamine (Calabresi et al., 1993; Tang et al., 2001; Picconi et al., 2004) to induce dopamine receptor hypersensitivity. With untreated mice, the inhibition of less active terminals by dopamine may contribute too little to the postsynaptic events. In contrast, by evaluating individual corticostriatal terminals, we are able to measure the entire population of events, similar to experiments using 4-aminopyridine-induced synaptic potentials to measure small events (minis) that are lost in large postsynaptic currents (FloresHernandez et al., 1994).

It is conceivable that the observed differences in corticostriatal function in DD mice are the result of altered basal glutamate levels rather than hypersensitive D2 receptors. We addressed this concern with two approaches: electron microscopy combined with glutamate immunolabeling and in vivo microdialysis. With this combination, we were able to measure the density of corticostriatal nerve terminal glutamate immunolabeling associated with the synaptic vesicle pool as well as the extracellular level of striatal glutamate. Both techniques showed no differences in glutamate between DD and control mice, suggesting that corticostriatal activity is maintained in the normal range in the absence of dopamine. These results suggest that the differences induced by D2 receptor agonists, L-dopa, cocaine, amphetamine, and striatal stimulation are most likely attributed to hypersensitive D2 receptors in DD mice, rather than alterations in basal striatal glutamate levels. These data are consistent with previous studies reporting that subchronic 1-methyl-4-phenyl-1,2,3,6-tetrahydropyridine (MPTP) treatment does not alter glutamate associated with the synaptic vesicle pool. Perhaps because DD mice are treated with L-dopa each day, there is sufficient dopamine to regulate cortical glutamate terminal density. In contrast, studies with complete 6-OHDA or MPTP lesions result in changes in terminal glutamate labeling, suggesting that changes in corticostriatal glutamate density are dependent on the degree of dopamine loss (Meshul et al., 1999; Meshul and Allen, 2000; S. Robinson et al., 2001, 2003).

In control mice, microdialysis demonstrated a decrease in extracellular glutamate after exposure to amphetamine, as shown by others (Miele et al., 2000). This was anticipated because FM1-43 destaining from corticostriatal terminals in the presence of amphetamine suggested a reduction in vesicular release of glutamate. Although DD mice demonstrated both behavioral changes and an amplified reduction in FM1-43 release with amphetamine, they failed to show alterations in extracellular glutamate. DD mice are hypersensitive to D1 receptor stimulation and manifest stereotypy and $c$-fos induction under conditions that do not affect control mice (Kim et al., 2000; Chartoff et al., 2001). The lack of effect of L-dopa and amphetamine on extracellular glutamate in DD mice might reflect a balance between a direct D2 receptor-mediated inhibition of corticostriatal release and an indirect D1 receptor-mediated stimulation of cortical neurons. Alternatively, changes in ambient glutamate because of the mutation may be too small to be resolved by microdialysis.

Surprisingly, in both DD and control mice, L-dopa appeared to have an inhibitory effect on the release of FM1-43. DD mice were given injections of L-dopa $1 \mathrm{hr}$ before they were killed. After preparation, the slices were allowed one additional hour to recover. Under these conditions, we assumed that most extracellu- lar dopamine would be cleared from the synaptic cleft. However, slices from L-dopa-treated DD mice showed slower corticostriatal terminal destaining halftimes compared with saline-treated DD mice. A similar, but less pronounced, effect was also seen in control mice after systemic L-dopa treatment. Residual tissue L-dopa may have access (mediated by slicing) to the intracellular enzyme L-AADC, which converts L-dopa to dopamine (Mercuri et al., 1990). This suggestion is supported by the effect of adding carbidopa, an L-AADC inhibitor, which significantly attenuated the destaining of slices from L-dopa-treated mice. Alternatively, L-dopa may have a direct effect on D2 receptors (Fisher et al., 2000) or may modify the spontaneous release of dopamine, leading to increased ambient synaptic dopamine levels (Zhou et al., 2001).

Our results suggest that the release of synaptic dopamine by physiologically relevant stimuli or by the psychostimulants amphetamine or cocaine depresses the release of glutamate from some cortical afferents but not others, thus selecting specific cortical responses for propagation through the basal ganglia. In DD mice, normal physiological selection is absent, most likely because of D2 receptor hypersensitivity. It is possible that in control mice, chronic dopamine action at certain D2 receptor containing terminals (but not all) results in the two (or more) terminal populations. In DD mice, all cortical terminals become hypersensitive because none are tonically occupied by dopamine.

It is tempting to believe that dopamine deficiency in humans, manifest in L-dopa-responsive dystonia (Segawa's disease) or Parkinson's disease, may also affect striatal excitation. Segawa's disease is characterized by dopamine deficiency with intact nigrostriatal innervation resulting from mutations in either the Th or the GTP cyclohydrolase gene (Nygaard, 1995). Patients with Segawa's disease present with fluctuating dystonia (Segawa, 1996) and evidence of hypersensitive D2 receptors (Kishore et al., 1998; Kunig et al., 1998). Pharmacological treatment with L-dopa in doses typical for treatment of Parkinson's disease may result in significant motor dyskinesias. Similarly, as the ability to release dopamine deteriorates in late stages of Parkinson's disease, changes in dopamine receptor sensitivity (Lee et al., 1978), and increased requirements for L-dopa often result in motor dyskinesias. Although these diseases represent a milder form of dopamine depletion compared with DD and reserpine-treated mice, alterations in dopamine receptor sensitivity would be expected to depress glutamate release from cortical afferents, effect the ability of the striatum to filter cortical information, and alter the postsynaptic integration of cortical information (Dani and Zhou, 2004). Thus, our findings support clinical evidence (Jenner, 2003) that the maintenance of stable brain dopamine concentrations may reduce hypersensitivity (Kim et al., 2000) and consequential untoward responses to treatment in these patients.

\section{References}

Akopian G, Walsh JP (2002) Corticostriatal paired-pulse potentiation produced by voltage-dependent activation of NMDA receptors and L-type $\mathrm{Ca}(2+)$ channels. J Neurophysiol 87:157-165.

Albin RL, Young AB, Penney JB (1989) The functional anatomy of basal ganglia disorders. Trends Neurosci 12:366-375.

Arbuthnott GW, Ingham CA, Wickens JR (1998) Modulation by dopamine of rat corticostriatal input. Adv Pharmacol 42:733-736.

Arnt J (1985) Behavioural stimulation is induced by separate dopamine D-1 and D-2 receptor sites in reserpine-pretreated but not in normal rats. Eur J Pharmacol 113:79-88.

Bamford NS, Zhang H, Schmitz Y, Wu NP, Cepeda C, Levine MS, Schmauss C, Zakharenko SS, Zablow L, Sulzer D (2004) Heterosynaptic dopamine neurotransmission selects sets of corticostriatal terminals. Neuron 42:653-663. 
Betz WJ, Bewick GS (1992) Optical analysis of synaptic vesicle recycling at the frog neuromuscular junction. Science 255:200-203.

Brown LL (1992) Somatotopic organization in rat striatum: evidence for a combinational map. Proc Natl Acad Sci USA 89:7403-7407.

Burt DR, Creese I, Snyder SH (1977) Antischizophrenic drugs: chronic treatment elevates dopamine receptor binding in brain. Science 196:326-328.

Calabresi P, Benedetti M, Mercuri NB, Bernardi G (1988) Endogenous dopamine and dopaminergic agonists modulate synaptic excitation in neostriatum: intracellular studies from naive and catecholamine-depleted rats. Neuroscience 27:145-157.

Calabresi P, De Murtas M, Mercuri NB, Bernardi G (1992) Chronic neuroleptic treatment: D2 dopamine receptor supersensitivity and striatal glutamatergic transmission. Ann Neurol 31:366-373.

Calabresi P, Mercuri NB, Sancesario G, Bernardi G (1993) Electrophysiology of dopamine-denervated striatal neurons. Implications for Parkinson's disease. Brain 116:433-452.

Callaway CW, Kuczenski R, Segal DS (1989) Reserpine enhances amphetamine stereotypies without increasing amphetamine-induced changes in striatal dialysate dopamine. Brain Res 505:83-90.

Cepeda C, Ariano MA, Calvert CR, Flores-Hernandez J, Chandler SH, Leavitt BR, Hayden MR, Levine MS (2001) NMDA receptor function in mouse models of Huntington disease. J Neurosci Res 66:525-539.

Chartoff EH, Marck BT, Matsumoto AM, Dorsa DM, Palmiter RD (2001) Induction of stereotypy in dopamine-deficient mice requires striatal D1 receptor activation. Proc Natl Acad Sci USA 98:10451-10456.

Dani JA, Zhou FM (2004) Selective dopamine filter of glutamate striatal afferents. Neuron 42:522-524.

Dube L, Smith AD, Bolam JP (1988) Identification of synaptic terminals of thalamic or cortical origin in contact with distinct medium-size spiny neurons in the rat neostriatum. J Comp Neurol 267:455-471.

Fisher A, Biggs CS, Eradiri O, Starr MS (2000) Dual effects of L-3,4dihydroxyphenylalanine on aromatic L-amino acid decarboxylase, dopamine release and motor stimulation in the reserpine-treated rat: evidence that behaviour is dopamine independent. Neuroscience 95:97-111.

Fisher RS, Levine MS, Sibley DR, Ariano MA (1994) D2 dopamine receptor protein location: Golgi impregnation-gold toned and ultrastructural analysis of the rat neostriatum. J Neurosci Res 38:551-564.

Flores-Hernandez J, Galarraga E, Pineda JC, Bargas J (1994) Patterns of excitatory and inhibitory synaptic transmission in the rat neostriatum as revealed by 4-AP. J Neurophysiol 72:2246-2256.

Flores-Hernandez J, Galarraga E, Bargas J (1997) Dopamine selects glutamatergic inputs to neostriatal neurons. Synapse 25:185-195.

Florin SM, Kuczenski R, Segal DS (1995) Effects of reserpine on extracellular caudate dopamine and hippocampus norepinephrine responses to amphetamine and cocaine: mechanistic and behavioral considerations. J Pharmacol Exp Ther 274:231-241.

Franklin KBJ, Paxinos G (1997) The mouse brain in stereotaxic coordinates. San Diego: Academic.

Garcia-Munoz M, Young SJ, Groves PM (1991) Terminal excitability of the corticostriatal pathway. II. Regulation by glutamate receptor stimulation. Brain Res 551:207-215.

Greenough WT, West RW, DeVoogd TJ (1978) Subsynaptic plate perforations: changes with age and experience in the rat. Science 202:1096-1098.

Harris KM (1995) How multiple-synapse boutons could preserve input specificity during an interneuronal spread of LTP. Trends Neurosci 18:365-369.

Hepler JR, Toomim CS, McCarthy KD, Conti F, Battaglia G, Rustioni A, Petrusz P (1988) Characterization of antisera to glutamate and aspartate. J Histochem Cytochem 36:13-22.

Hernandez-Lopez S, Tkatch T, Perez-Garci E, Galarraga E, Bargas J, Hamm H, Surmeier DJ (2000) D2 dopamine receptors in striatal medium spiny neurons reduce L-type $\mathrm{Ca}^{2+}$ currents and excitability via a novel PLC[beta] 1-IP3-calcineurin-signaling cascade. J Neurosci 20:8987-8995.

Hsu KS, Huang CC, Yang CH, Gean PW (1995) Presynaptic D2 dopaminergic receptors mediate inhibition of excitatory synaptic transmission in rat neostriatum. Brain Res 690:264-268.

Ito K, Haga T, Lameh J, Sadee W (1999) Sequestration of dopamine D2 receptors depends on coexpression of G-protein-coupled receptor kinases 2 or 5. Eur J Biochem 260:112-119.

Jaber M, Fournier MC, Bloch B (1992) Reserpine treatment stimulates enkephalin and D2 dopamine receptor gene expression in the rat striatum. Brain Res Mol Brain Res 15:189-194.
Jenner P (2003) Dopamine agonists, receptor selectivity and dyskinesia in duction in Parkinson's disease. Curr Opin Neurol 16 [Suppl 1]:S3-S7.

Jog MS, Kubota Y, Connolly CI, Hillegaart V, Graybiel AM (1999) Building neural representations of habits. Science 286:1745-1749.

Jones SR, Gainetdinov RR, Wightman RM, Caron MG (1998) Mechanisms of amphetamine action revealed in mice lacking the dopamine transporter. J Neurosci 18:1979-1986.

Kay AR, Alfonso A, Alford S, Cline HT, Holgado AM, Sakmann B, Snitsarev VA, Stricker TP, Takahashi M, Wu LG (1999) Imaging synaptic activity in intact brain and slices with FM1-43 in C. elegans, lamprey, and rat. Neuron 24:809-817.

Kim DS, Szczypka MS, Palmiter RD (2000) Dopamine-deficient mice are hypersensitive to dopamine receptor agonists. J Neurosci 20:4405-4413.

Kishore A, Nygaard TG, de la Fuente-Fernandez R, Naini AB, Schulzer M, Mak E, Ruth TJ, Calne DB, Snow BJ, Stoessl AJ (1998) Striatal D2 receptors in symptomatic and asymptomatic carriers of dopa-responsive dystonia measured with [11C]-raclopride and positron-emission tomography. Neurology 50:1028-1032.

Koob GF (1992) Drugs of abuse: anatomy, pharmacology and function of reward pathways. Trends Pharmacol Sci 13:177-184.

Kunig G, Leenders KL, Antonini A, Vontobel P, Weindl A, Meinck HM (1998) D2 receptor binding in dopa-responsive dystonia. Ann Neurol 44:758-762.

LaHoste GJ, Marshall JF (1994) Rapid development of D1 and D2 dopamine receptor supersensitivity as indicated by striatal and pallidal Fos expression. Neurosci Lett 179:153-156.

LaHoste GJ, Yu J, Marshall JF (1993) Striatal Fos expression is indicative of dopamine D1/D2 synergism and receptor supersensitivity. Proc Natl Acad Sci USA 90:7451-7455.

Larsen KE, Fon EA, Hastings TG, Edwards RH, Sulzer D (2002) Methamphetamine-induced degeneration of dopaminergic neurons involves autophagy and upregulation of dopamine synthesis. J Neurosci 22:8951-8960.

Lee T, Seeman P, Rajput A, Farley IJ, Hornykiewicz O (1978) Receptor basis for dopaminergic supersensitivity in Parkinson's disease. Nature 273:59-61.

Levesque M, Charara A, Gagnon S, Parent A, Deschenes M (1996) Corticostriatal projections from layer $\mathrm{V}$ cells in rat are collaterals of long-range corticofugal axons. Brain Res 709:311-315.

Mainen ZF, Maletic-Savatic M, Shi SH, Hayashi Y, Malinow R, Svoboda K (1999) Two-photon imaging in living brain slices. Methods 18:231- 239.

Maura G, Giardi A, Raiteri M (1988) Release-regulating D-2 dopamine receptors are located on striatal glutamatergic nerve terminals. J Pharmacol Exp Ther 247:680-684.

Mercuri NB, Calabresi P, Bernardi G (1990) Responses of rat substantia nigra compacta neurones to L-DOPA. Br J Pharmacol 100:257-260.

Meshul CK, Allen C (2000) Haloperidol reverses the changes in striatal glutamatergic immunolabeling following a 6-OHDA lesion. Synapse 36:129-142.

Meshul CK, Stallbaumer RK, Taylor B, Janowsky A (1994) Haloperidolinduced morphological changes in striatum are associated with glutamate synapses. Brain Res 648:181-195.

Meshul CK, Emre N, Nakamura CM, Allen C, Donohue MK, Buckman JF (1999) Time-dependent changes in striatal glutamate synapses following a 6-hydroxydopamine lesion. Neuroscience 88:1-16.

Meshul CK, Kamel D, Moore C, Kay TS, Krentz L (2002) Nicotine alters striatal glutamate function and decreases the apomorphine-induced contralateral rotations in 6-OHDA-lesioned rats. Exp Neurol 175:257-274.

Miele M, Mura MA, Enrico P, Esposito G, Serra PA, Migheli R, Zangani D, Miele E, Desole MS (2000) On the mechanism of d-amphetamineinduced changes in glutamate, ascorbic acid and uric acid release in the striatum of freely moving rats. Br J Pharmacol 129:582-588.

Niddam R, Arbilla S, Scatton B, Dennis T, Langer SZ (1985) Amphetamine induced release of endogenous dopamine in vitro is not reduced following pretreatment with reserpine. Naunyn Schmiedebergs Arch Pharmacol 329:123-127.

Nygaard TG (1995) Dopa-responsive dystonia. Curr Opin Neurol 8:310-313.

O’Donnell P, Grace AA (1994) Tonic D2-mediated attenuation of cortical excitation in nucleus accumbens neurons recorded in vitro. Brain Res 634:105-112.

Paladini CA, Robinson S, Morikawa H, Williams JT, Palmiter RD (2003) 
Dopamine controls the firing pattern of dopamine neurons via a network feedback mechanism. Proc Natl Acad Sci USA 100:2866-2871.

Pasinetti GM, Morgan DG, Johnson SA, Millar SL, Finch CE (1990) Tyrosine hydroxylase mRNA concentration in midbrain dopaminergic neurons is differentially regulated by reserpine. J Neurochem 55:1793-1799.

Paul ML, Graybiel AM, David JC, Robertson HA (1992) D1-like and D2like dopamine receptors synergistically activate rotation and c-fos expression in the dopamine-depleted striatum in a rat model of Parkinson's disease. J Neurosci 12:3729-3742.

Phend KD, Weinberg RJ, Rustioni A (1992) Techniques to optimize postembedding single and double staining for amino acid neurotransmitters. J Histochem Cytochem 40:1011-1020.

Picconi B, Centonze D, Rossi S, Bernardi G, Calabresi P (2004) Therapeutic doses of L-dopa reverse hypersensitivity of corticostriatal D2-dopamine receptors and glutamatergic overactivity in experimental parkinsonism. Brain 127:1661-1669.

Pickel VM, Beckley SC, Joh TH, Reis DJ (1981) Ultrastructural immunocytochemical localization of tyrosine hydroxylase in the neostriatum. Brain Res 225:373-385.

Rios M, Habecker B, Sasaoka T, Eisenhofer G, Tian H, Landis S, Chikaraishi D, Roffler-Tarlov S (1999) Catecholamine synthesis is mediated by tyrosinase in the absence of tyrosine hydroxylase. J Neurosci 19:3519-3526.

Robinson DL, Phillips PE, Budygin EA, Trafton BJ, Garris PA, Wightman RM (2001) Sub-second changes in accumbal dopamine during sexual behavior in male rats. NeuroReport 12:2549-2552.

Robinson S, Krentz L, Moore C, Meshul CK (2001) Blockade of NMDA receptors by MK- 801 reverses the changes in striatal glutamate immunolabeling in 6-OHDA-lesioned rats. Synapse 42:54-61.

Robinson S, Freeman P, Moore C, Touchon JC, Krentz L, Meshul CK (2003) Acute and subchronic MPTP administration differentially affects striatal glutamate synaptic function. Exp Neurol 180:74-87.

Robinson TE, Whishaw IQ (1988) Normalization of extracellular dopamine in striatum following recovery from a partial unilateral 6-OHDA lesion of the substantia nigra: a microdialysis study in freely moving rats. Brain Res 450:209-224.

Ryan TA, Reuter H, Wendland B, Schweizer FE, Tsien RW, Smith SJ (1993) The kinetics of synaptic vesicle recycling measured at single presynaptic boutons. Neuron 11:713-724.

Schmitz Y, Lee CJ, Schmauss C, Gonon F, Sulzer D (2001) Amphetamine distorts stimulation-dependent dopamine overflow: effects on D2 autoreceptors, transporters, and synaptic vesicle stores. J Neurosci 21:5916-5924.

Schultz W (1982) Depletion of dopamine in the striatum as an experimental model of Parkinsonism: direct effects and adaptive mechanisms. Prog Neurobiol 18:121-166.

Schuster R (1988) Determination of amino acids in biological, pharmaceutical, plant and food samples by automated precolumn derivatization and high-performance liquid chromatography. J Chromatogr 431:271-284.

Segawa M (1996) [Segawa disease (hereditary progressive dystonia with marked diurnal fluctuation-HPD) and abnormalities in pteridin metabolism]. Rinsho Shinkeigaku 36:1322-1323.

Sesack SR, Aoki C, Pickel VM (1994) Ultrastructural localization of D2 receptor-like immunoreactivity in midbrain dopamine neurons and their striatal targets. J Neurosci 14:88-106.

Smith Y, Bennett BD, Bolam JP, Parent A, Sadikot AF (1994) Synaptic relationships between dopaminergic afferents and cortical or thalamic input in the sensorimotor territory of the striatum in monkey. J Comp Neurol 344:1-19.

Sulzer D, Pothos EN (2000) Regulation of quantal size by presynaptic mechanisms. Rev Neurosci 11:159-212.

Sulzer D, St Remy C, Rayport S (1996) Reserpine inhibits amphetamine action in ventral midbrain culture. Mol Pharmacol 49:338-342.

Szczypka MS, Rainey MA, Kim DS, Alaynick WA, Marck BT, Matsumoto AM, Palmiter RD (1999) Feeding behavior in dopamine-deficient mice. Proc Natl Acad Sci USA 96:12138-12143.

Tang K, Low MJ, Grandy DK, Lovinger DM (2001) Dopamine-dependent synaptic plasticity in striatum during in vivo development. Proc Natl Acad Sci USA 98:1255-1260.

Thomas SA, Marck BT, Palmiter RD, Matsumoto AM (1998) Restoration of norepinephrine and reversal of phenotypes in mice lacking dopamine beta-hydroxylase. J Neurochem 70:2468-2476.

Traub M, Reches A, Wagner HR, Fahn S (1986) Reserpine-induced upregulation of dopamine $\mathrm{D} 2$ receptors in the rat striatum is enhanced by denervation but not by chronic receptor blockade. Neurosci Lett 70:245-249.

Van der Kloot W (1991) The regulation of quantal size. Prog Neurobiol 36:93-130.

Wang H, Pickel VM (2002) Dopamine D2 receptors are present in prefrontal cortical afferents and their targets in patches of the rat caudateputamen nucleus. J Comp Neurol 442:392-404.

West AR, Grace AA (2002) Opposite influences of endogenous dopamine D1 and D2 receptor activation on activity states and electrophysiological properties of striatal neurons: studies combining in vivo intracellular recordings and reverse microdialysis. J Neurosci 22:294-304.

West AR, Galloway MP, Grace AA (2002) Regulation of striatal dopamine neurotransmission by nitric oxide: effector pathways and signaling mechanisms. Synapse 44:227-245.

Williams J, Lacey M (1988) Actions of cocaine on central monoamine neurons: intracellular recordings in vitro. NIDA Res Monogr 90:234-242.

Wilson CJ (1987) Morphology and synaptic connections of crossed corticostriatal neurons in the rat. J Comp Neurol 263:567-580.

Wilson CJ (1990) Basal ganglia. In: The synaptic organization of the brain (Shepherd GW, ed), pp 279-316. Oxford: Oxford UP.

Wilson CJ (1995) Corticostriatal neurons of the medial agranular cortex in rats. In: Functions of the cortico-basal ganglia loop (Kimura M, Graybiel AM, eds), pp 50-72. Tokyo: Springer.

Zakharenko SS, Zablow L, Siegelbaum SA (2001) Visualization of changes in presynaptic function during long-term synaptic plasticity. Nat Neurosci 4:711-717.

Zhou FM, Liang Y, Dani JA (2001) Endogenous nicotinic cholinergic activity regulates dopamine release in the striatum. Nat Neurosci 4:1224-1229.

Zhou QY, Palmiter RD (1995) Dopamine-deficient mice are severely hypoactive, adipsic, and aphagic. Cell 83:1197-1209. 